Article

\title{
Analysis of a Hybrid Solar-Assisted Trigeneration System
}

\author{
Elisa Marrasso *, Carlo Roselli, Maurizio Sasso and Francesco Tariello \\ Department of Engineering, University of Sannio, Piazza Roma 21, 82100 Benevento, Italy; \\ carlo.roselli@unisannio.it (C.R.); sasso@unisannio.it (M.S.); francesco.tariello@unisannio.it (F.T.) \\ * Correspondence: marrasso@unisannio.it; Tel.: +39-0824-305576; Fax: +39-0824-325246 \\ Academic Editor: Francesco Calise \\ Received: 31 May 2016; Accepted: 24 August 2016; Published: 1 September 2016
}

\begin{abstract}
A hybrid solar-assisted trigeneration system is analyzed in this paper. The system is composed of a $20 \mathrm{~m}^{2}$ solar field of evacuated tube collectors, a natural gas fired micro combined heat and power system delivering $12.5 \mathrm{~kW}$ of thermal power, an absorption heat pump (AHP) with a nominal cooling power of $17.6 \mathrm{~kW}$, two storage tanks (hot and cold) and an electric auxiliary heater (AH). The plant satisfies the energy demand of an office building located in Naples (Southern Italy). The electric energy of the cogenerator is used to meet the load and auxiliaries electric demand; the interactions with the grid are considered in cases of excess or over requests. This hybrid solution is interesting for buildings located in cities or historical centers with limited usable roof surface to install a conventional solar heating and cooling (SHC) system able to achieve high solar fraction (SF). The results of dynamic simulation show that a tilt angle of $30^{\circ}$ maximizes the $S F$ of the system on annual basis achieving about $53.5 \%$. The influence on the performance of proposed system of the hot water storage tank (HST) characteristics (volume, insulation) is also studied. It is highlighted that the $S F$ improves when better insulated and bigger HSTs are considered. A maximum SF of about $58.2 \%$ is obtained with a $2000 \mathrm{~L}$ storage, whereas the lower thermal losses take place with a better insulated 1000 L tank.
\end{abstract}

Keywords: microcogeneration; trigeneration system; solar collector; dynamic simulation; solar energy; hybrid system

\section{Introduction}

In the European Union, energy consumption in the residential sector with respect to the total final energy use increased from $37.4 \%$ to $40.6 \%$ in the period 2011-2013 [1,2]. The global energy demand for civil and tertiary sectors also surpassed other energy consumption sectors such as industry, reaching only $25.1 \%$ in 2013 [2]. This energy consumption contributed up to $46 \%$ of global annual greenhouse gas (GHG) emissions in the European Union (EU-27) during 2012 [3].

The increase of the energy demand for heating, cooling and air-conditioning is linked to the rise in thermal and cooling loads, the greater comfort expectations in buildings and the social and economic development [4]. This trend has caused not only high peaks of electricity consumption in summer due to the great diffusion of conventional vapor-compression chillers, threatening the stability of the power grids [5], but it has also led to major environmental problems since about the $50 \%$ of electricity in EU is supplied by power stations burning fossil fuels [6]. Therefore, it is important to find alternative energy conversion systems that allow to meet the energy demands of buildings, reduce their primary energy consumption and GHG emissions taking into account the depletion of conventional energy sources. Capellán-Pérez et al. [7] estimated that from 2020 to 2030 the difference between the total primary energy demand and fossil fuels extraction will be significant. They concluded that a strong effort to 
compensate the decreasing of fossil fuels availability using renewable resources, improving energy efficiency and adopting alternative policy is required.

Solar heating and cooling (SHC) systems can mitigate this issue by partially meeting the cooling demand during the summer season and the heating demand during the winter period. There are several alternative solutions for SHC but all are fed by the solar energy collected by a solar field. The main advantage of these systems is related to the simultaneity between the cooling needs and the source availability in the summer period, especially for hot climates [8]. In fact, in the last few years, different numerical and experimental studies were conducted on the solar assisted systems and some institutions were also involved in R\&D activities in this field. The International Energy Agency (IEA) developed research projects to promote and to give guidelines on various aspects of SHC systems within the IEA SHC Programme [9]. According to the IEA Technology Roadmap on SHC [5], the SHC systems should cover up to $17 \%$ of the worldwide cooling needs by 2050 .

Due to the uncertainty of the source, solar-driven systems are usually equipped with thermal storage tanks and backup devices in order to compensate the absence or the low solar radiation. For a SHC system, there are two different backup options: gas-fired boilers that integrate the solar thermal production in heating and cooling operation; or electric heat pumps that allow always to meet the users heating and cooling demands if there is no radiation.

In the historical centers, where buildings are subject to legislative and landscape restrictions, or in town centers, often characterized by multi-story buildings, there is a lack of roof area with an available or usable surface to place a solar field large enough to satisfy a great fraction of the heating and cooling demands of the end users. In these cases the integrated systems have to be installed and operated simultaneously (not only in replacement of solar-activated devices) supplying significant share of energy in the plant. Since these peaking/backup devices have to be operated for long periods, it could be advantageous to use polygeneration systems, which are generally more efficient with respect to the conventional backup components (boilers, electric heat pumps). Therefore it seems more appropriate to refer to these solar and fossil fuels driven systems as hybrid solar-assisted systems and not as SHC systems.

Many studies based on experimental or simulated models have been reported in literature in order to investigate different possible configurations of the SHC systems and their potential for the residential sectors applications. Among different solar driven cooling systems, the attention will focus on the absorption cooling systems presented in the market in different power ranges and used for air conditioning in the civil sector.

Shirazi et al. [10] carried out a performance analysis of four configurations of SHC systems based on evacuated tube collectors coupled with a single-effect AHP. In the first two plants, the AHP was selected to cover the maximum cooling demands of the analyzed building. A gas-fired boiler was considered as auxiliary heating system in the first layout and an electric vapor-compression chiller as cooling backup device in the second configuration. The third and fourth layout differed from the second for the size of AHP, which was designed to balance only $50 \%$ and $20 \%$ of the cooling demand, respectively. The authors developed a simulation model with TRNSYS software (Solar Energy Laboratory, University of Wisconsin-Madison, Madison, WI, USA) [11] in order to select the optimal systems design parameters and they compared the energy, environmental and economic performance of the systems with a reference conventional Heating Ventilation and Air-Conditioning (HVAC) plant that consisted of a water cooled vapor-compression chiller and a gas boiler. They found that the second configuration achieves the best energy and environmental performance, ensuring a primary energy saving of $54.5 \%$ and a reduction of up to $146 \mathrm{t}$ per year of equivalent $\mathrm{CO}_{2}$ emissions compared to the reference HVAC system. The results of the analysis showed that all the configurations were economically feasible only in presence of a government subsidy.

Calise [12] developed a simulation model of a SHC system consisting of parabolic collectors with a double effect AHP and a biomass-fired heater used in heating and cooling operation. The plant was designed to satisfy the heating, cooling and domestic hot water demand of a small university 
hall. The analysis provides a parametric optimization of the design system variables and investigates the economic and energy system performance in seven different Mediterranean cities. The proposed system was also compared to a SHC system in which the biomass heater was replaced by gas fuelled heater in order to evaluate the influence of biomass on the system performance. The results showed that the system based on renewable sources achieved a primary energy saving of about $80 \%$ in all investigated cities and the payback period was lower than system operating life for most of the cities considered.

Baniyouners et al. [13] introduced a simulation model of a solar assisted air conditioning system for an office building under three different subtropical climates in Australia. The system consisted of a single effect $\mathrm{LiBr}-\mathrm{H}_{2} \mathrm{O}$ AHP coupled with flat plate collectors. The plant was designed to supply the cooling and hot water demand of the office user. The cooling load profile of the building was obtained using TRNSYS Software under the influence of these different climates. This study investigated variables affecting the performance system such as solar collectors (SC) area and hot water volume; in addition the primary energy saving achieved by system compared to an electric vapor compression heat pump, was evaluated. The results showed that $80 \%$ of primary energy saving was achieved by installing $50 \mathrm{~m}^{2}$ of SC and $1.8 \mathrm{~m}^{3}$ of hot water storage tank (HST) under the three selected climates.

Zhai et al. [14] described a solar absorption cooling system designed and installed to meet the cooling demand of a test room with the area of $50 \mathrm{~m}^{2}$. A solar field of evacuated tube collectors, a $3 \mathrm{~m}^{3}$ storage tank, an $8 \mathrm{~kW} \mathrm{LiBr} / \mathrm{H}_{2} \mathrm{O}$ single effect absorption chiller and a cooling tower (CT) are the main components of the plant. Fan coils and a radiant cooling ceiling are the terminals used in the test-room. With the radiant system an average higher cooling output was achieved $(4.5 \mathrm{~kW})$ while the chiller efficiency was 0.32 . Furthermore, the authors evaluated the indoor comfort condition obtaining a predicted mean vote of 0.22 and a predicted percentage dissatisfied of 5.89 .

Drosou et al. [15] discussed the feasibility of a solar cooling system using parabolic trough solar concentrators and double-effect absorption chiller to meet the cooling demands of two office buildings in Greece. The authors found that concentrated SC are an interesting solution to couple with more efficient AHP (double-effect). They also observed that solar concentrators can be installed when there is limited availability of space on the roof to use conventional SC (flat plate or evacuated tube). Simulation results revealed that thermal energy output $(1297 \mathrm{MWh} / \mathrm{y})$ of the solar field of parabolic trough collectors (simulated with Greenius simulation tool) can reasonably meet the cooling demands of the office buildings (simulated with Energy Plus software).

Often the SHC systems studied in literature are integrated with boilers and/or electric heat pumps, but this is not the only solution. In very hot weather climate sometime, for example, there is not a backup system. Mohan et al. [16] experimentally analysed a solar thermal polygeneration plant composed of evacuated tube SC, a single effect absorption chiller and a membrane distillation unit installed in United Arab Emirates. This plant was designed for a high flexibility, with four different modes of operation available: as a solar cooling system for air-conditioning an office cabin, as a cogenerator that desalinates sea water and heats up domestic hot water, as a cogenerator that provides air-conditioning and desalinated water, and, finally, as trigeneration system for air-conditioning, drinking and domestic hot water. The authors evaluate that such a system could obtain a potential payback period of 9.08 years. On the other hand, however, the coupling of solar systems with high-efficiency energy conversion devices, such as cogeneration systems, is a solution designed only in few cases, even if the two technologies have been widely investigated separately.

In the study of Suárez et al. [17], a plant based on a thermal solar system and a cogeneration unit, which satisfied, respectively, the domestic hot water and space heating demand of four residential buildings located in Spain, was investigated. The electricity provided by the cogeneration system was sold to the power grid.

The authors analyzed different system configurations varying the number and the orientation of collectors, the way in which the buildings are grouped, the type of micro-turbines used in cogeneration system and their daily and yearly operation periods. They also compared the system performance 
with those obtained considering the two technologies separately with the integration of an existing auxiliary boiler. The results highlighted that the system integrating both technologies in a centralized installation for the four buildings achieves the best energy and environmental performance. In this scenario, the auxiliary boiler was completely replaced by the cogeneration system in order to increase its annual operation period and to obtain best environmental performance by means of the better use of fuel. The payback period was evaluated as lower than 8 years.

Kegel et al. [18] performed a comparison of different solar thermal, cogeneration and thermally driven heating/cooling systems to supply the energy demands of a typical apartment in Canada. They evaluated the GHG emissions, the annual costs savings and the primary energy consumption of various system configurations with respect to the base case. The simulation results showed that the best performance was obtained when priority is given to the cogenerator thermal production with respect to the solar thermal collectors and when the cogenerated thermal energy is used to activate an AHP. In this case the system can achieve an annual cost saving and avoided GHG emissions of $21 \%$ and $16 \%$, respectively. The authors also compared the best layout system to the cogeneration system only. They obtained a primary energy saving of $12 \%$ in order to demonstrate the benefit of integrating the SC and thermally-driven heat pump with the cogeneration unit.

In the study of Ribberink et al. [19], a hybrid system consisting of a cogenerator based on a Stirling-engine coupled with solar thermal collectors was modeled, simulated and compared to a base case system without solar energy input applied in various Canada locations. The results showed that by adding the SC it was possible to reduce the natural gas consumption of about $10 \%-15 \%$ and to reduce 700-1200 kg per year of GHG emissions for each house, depending on the location and the system layout.

The literature review pointed out that the hybrid systems consisting of a cogenerator coupled with a SC field, are more suitable in the climates with predominantly cold seasons, where large amounts of thermal energy are needed to satisfy space heating requests. In region with hot climates like Mediterranean areas, it is necessary to add a thermally-driven system that meets the cooling demand of buildings, in order to achieve significant operation hours of both the cogenerators and the SC. Furthermore, in the literature, there are some examples of alternative systems for the combined production of heat/cooling and electricity. For example, Muye et al. [20] analyzed the annual performance of a solar driven ammonia-water absorption power and cooling system with a biomass auxiliary installed in Seville, Spain, and Chennai, India. A scroll expander was considered for the generation of power. They evaluated the effect of heat source temperature, cooling water inlet temperature and the chilled fluid inlet temperature on the revised Goswamy cycle. This thermodynamic cycle was simulated with Engineering Equation Solver software and then used in TRNSYS to simulate the innovative solar cooling and power plant. The system produced more power and cooling and a better annual efficiency in Seville $(6 \%-8 \%)$ than in Chennai $(5 \%-7 \%)$. Nonetheless, Chennai had a superior annual solar contribution ( $23 \%-30 \%)$ than Seville $(24 \%-28 \%)$.

These hybrid systems are very complex; therefore, a detailed optimization tool is required to perform a correct design and control. They are also characterized by very high installation costs and acceptable payback periods are quite difficult to be obtained.

In the following sections a hybrid solar-assisted trigeneration system based on micro combined heating and power (micro-CHP) coupled to solar thermal collectors and an AHP, able to provide both space heating and cooling to a three story office located in Naples, is investigated through dynamic simulations. The influence of the tilt angle on solar fraction $(S F)$ is studied in order to maximize the share of heating and cooling demand satisfied by the renewable energy source. Furthermore, how the system performance (in terms of $S F$ and tank thermal losses) changes with the characteristics of the HST (volume and insulation) is assessed.

A trigeneration system such as that discussed below, in which two non-conventional technologies (SC and cogenerator) are coupled, is not a solution studied before by other authors, in particular for installation in the Mediterranean area. This plant can be an attractive solution for applications where 
there is a lack of free or available surfaces on the roof to install a solar field that allows to have a high $S F$. In this case, the choice of a backup system, that has a higher overall conversion efficiency, results in significant primary energy savings compared to the conventional SHC and air conditioning systems.

\section{User and Building Description}

The building analyzed in this work is a three-story office (Figure 1). The area of each floor is equal to $81 \mathrm{~m}^{2}$ and the total heated/cooled volume is $729 \mathrm{~m}^{3}$. The building is located in Naples (1034 heating degree day, HDD) and the characteristics of its envelope are reported in Table 1 . The transmittance of each component is in agreement with the constraints of Italian legislation [21]. The equivalent transmittance of ground floor calculated with reference to [22], considering the ground (sand or gravel with conductivity equal to $2.0 \mathrm{~W} /(\mathrm{m} \cdot \mathrm{K})$ ) interacting with basement floor layer, is equal to $0.210 \mathrm{~W} /\left(\mathrm{m}^{2} \cdot \mathrm{K}\right)$. The transmittance of windows takes into account transmittance of both the window frame ( $17 \%$ of the total surface) and the glass. Moreover, the glazed surface is equal to about $20 \%$ of the floor area for each level. Table 1 also shows the g-value (total solar energy transmittance) of the transparent surface. In order to reduce the solar gain in summer period, an automatic shading device is installed for each window. It reduces the incident radiation to $35 \%$ when the irradiation is greater than $300 \mathrm{~W} / \mathrm{m}^{2}$.

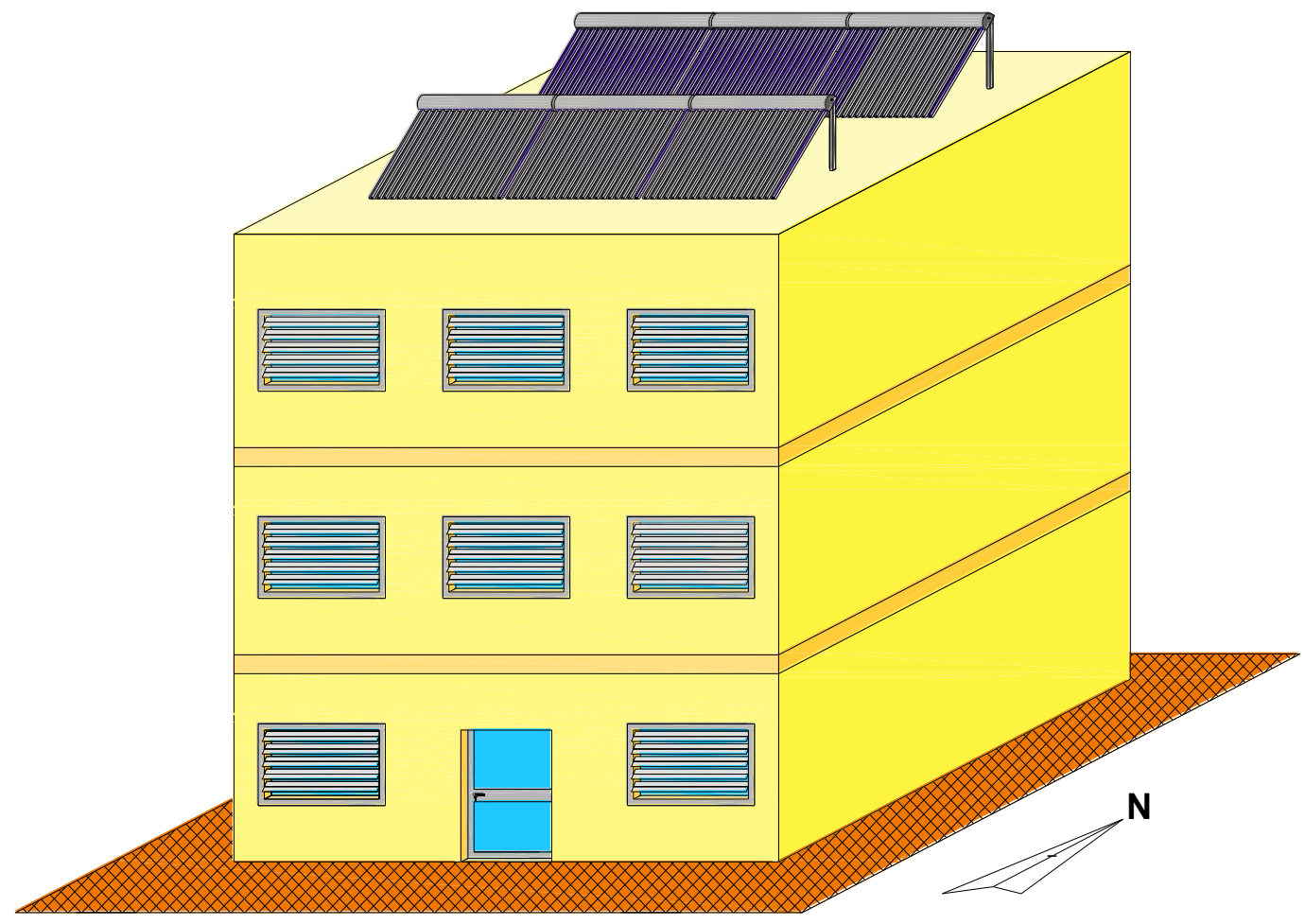

Figure 1. Three-story office building.

Table 1. Main characteristics of building envelope.

\begin{tabular}{cccc}
\hline Building Element & Transmittance $\left(\mathrm{W} / \mathrm{m}^{\mathbf{2}} \cdot \mathbf{K}\right)$ & Thermal Mass $\left(\mathbf{k g} / \mathbf{m}^{\mathbf{2}}\right)$ & $\mathrm{g}$-Value (-) \\
\hline External wall & 0.39 & 373 & - \\
Roof & 0.37 & 322 & - \\
Ground floor & 0.42 & 680 & - \\
Window & 2.29 & - & 0.608 \\
\hline
\end{tabular}

The electricity yearly demand of the building, $51.4 \mathrm{kWh} / \mathrm{m}^{2}$, is defined according to the target value for office building reported in [23]. The daily electric demand of each floor of buildings, defined 
according to [24] for a weekend day and a week day is reported in Figure 2. Figure 3 shows the occupancy schedule of each floor in a work day considering a maximum occupancy of five people per floor. In the weekend days, there are no occupants in the office.

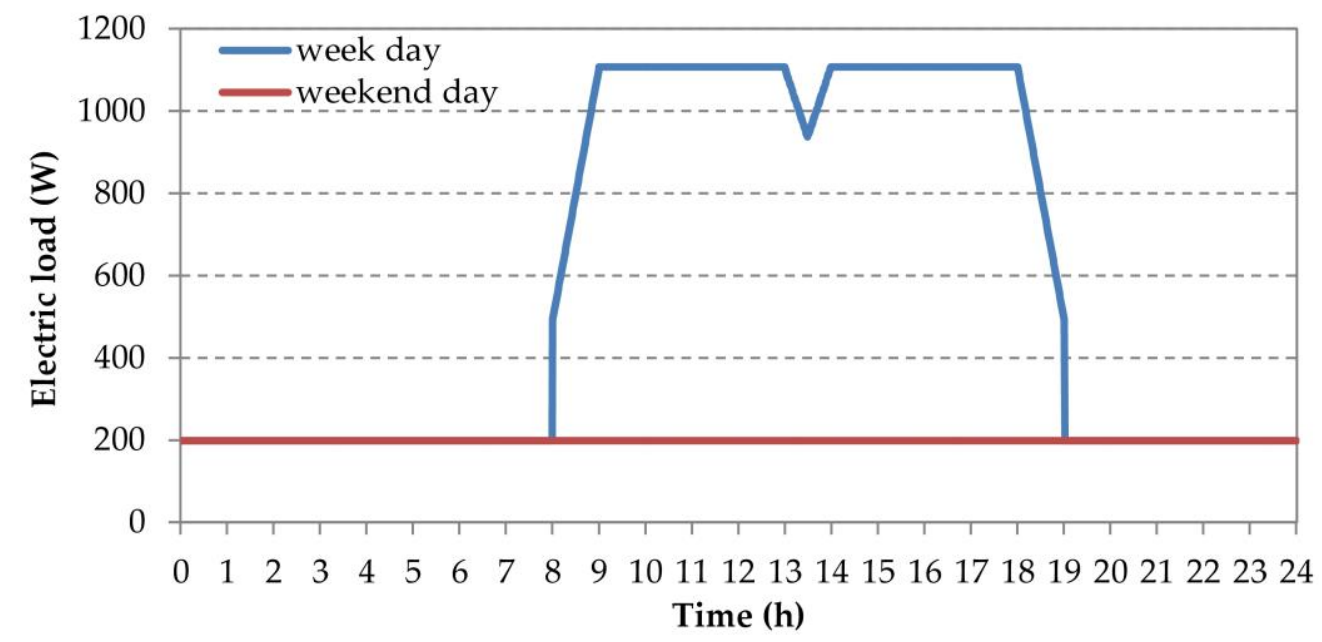

Figure 2. Electric load profile for each floor.

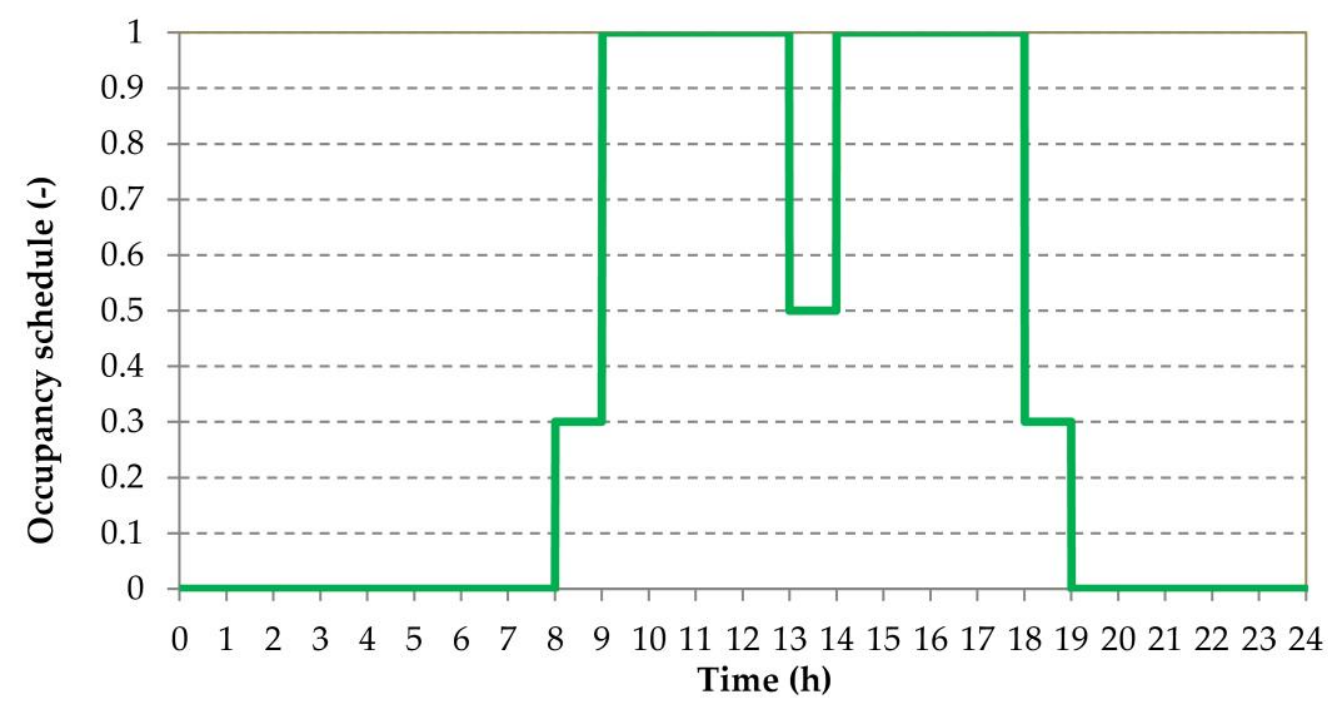

Figure 3. Occupancy schedule in a work day.

Air changing rate for the building is assumed equal to $11 \times 10^{-3} \mathrm{~m}^{3} / \mathrm{s}$ per person [25], which for this application considered becomes $594 \mathrm{~m}^{3} / \mathrm{h}$. The domestic hot water demand is negligible with respect to the heating load.

According to Italian legislation, the heating period for Naples is from 15 November to 31 March and the indoor set-point air temperature is $20.0^{\circ} \mathrm{C}\left( \pm 0.5^{\circ} \mathrm{C}\right)$; the operation time of the heating system is assumed between 8:00 and 18:00, in a working day while during weekend the heating system is turned off. The cooling period is from 1 June to 30 September, and in these months, during the working days, the desired temperature is $26^{\circ} \mathrm{C}\left( \pm 0.5^{\circ} \mathrm{C}\right)$. During the intermediate period (1 April-31 May and 1 October-14 November) there is no space heating or cooling demand, the cogenerator is turned off and the SC are covered to avoid dissipating solar thermal energy continuously. The building is simulated by means of TRNSYS software. Heating and cooling load are reported in Figure 4a, b, respectively. The peaks of heat and cooling loads are about $26 \mathrm{~kW}$ and $35 \mathrm{~kW}$, respectively. The total heating and cooling energy demands are $4.79 \mathrm{MWh} / \mathrm{y}$ and $6.03 \mathrm{MWh} / \mathrm{y}$, respectively. 


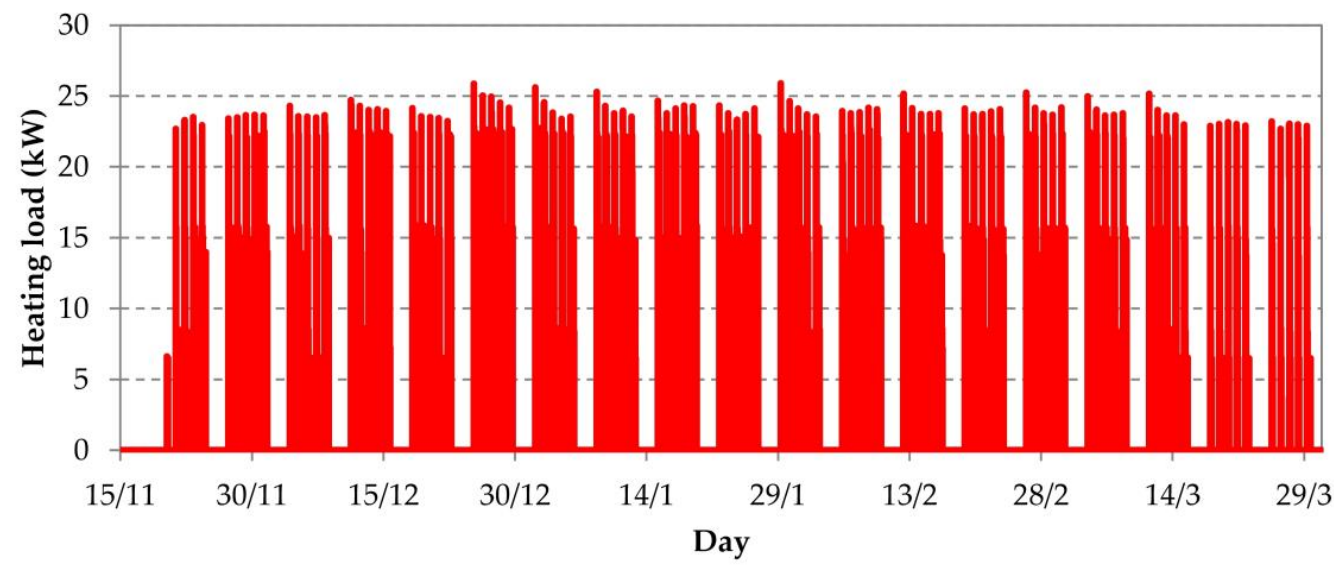

(a)

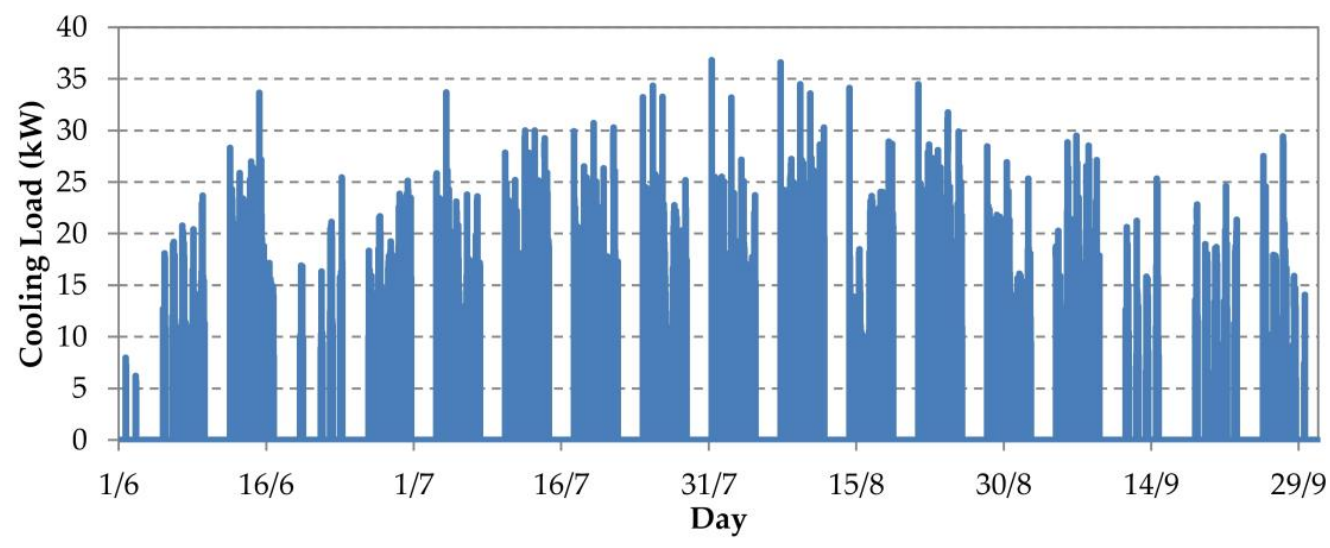

(b)

Figure 4. (a) Heating and (b) cooling loads.

\section{System Configuration}

In order to satisfy electricity, thermal and cooling demands of the office, a hybrid solar-assisted trigeneration system is here analyzed through dynamic simulations. The two main heat sources in the plant are a micro combined heat and power (micro-CHP) [26] delivering $12.5 \mathrm{~kW}_{\text {th }}$ and $5.5 \mathrm{~kW}_{\mathrm{el}}$ and a solar field of six evacuated tube collectors [27], arranged in two rows facing South (Figure 5). The SC are placed on the roof of building and have an aperture area of $20.6 \mathrm{~m}^{2}$. In the cooling period, the two heat sources heat up the water stored in the $1000 \mathrm{~L}$ hot HST in order to keep it at a temperature greater than $70{ }^{\circ} \mathrm{C}$, which is the minimum temperature to activate the $17.6 \mathrm{~kW}_{\mathrm{co}} \mathrm{AHP}$ [28].

In both operating conditions (cooling, Figure 5 and heating, Figure 6), the plant could be split in three sub-systems with different control strategies:

(1) the heating sub-system, composed by the SC, the internal combustion engine micro-CHP, HST, the dry cooler (DC) and the electric auxiliary heater (AH);

(2) the distribution and cooling sub-system, composed by the valves, the AHP, the CT and the cold water storage tank (CST); and

(3) the building.

The control strategy for the heating sub-system provides that the pump, P1, is activated moving the working fluid (water/glycol mixture), when the temperature at the collectors outlet is greater than that one at the lower part of the tank where the solar circuit is connected to the heat exchanger (Figure 5). The cogenerator is turned on only during the opening hours of the weekdays, if the temperature in the upper zone of the HST is lower than $70{ }^{\circ} \mathrm{C}$. The solar subsystem, instead, can operate always 
during week and weekend days, when the tank is sufficiently cold. A security system consisting of a $\mathrm{DC}$ is used to prevent the temperature in the solar loop from approaching $100{ }^{\circ} \mathrm{C}$. Finally, a further electric $\mathrm{AH}$ is considered as back-up device when both the solar system and the micro-CHP do not allow to satisfy the heating and cooling demand. A similar control strategy for the heating sub-system is implemented in the heating operation (Figure 6). The main difference concerns the activation temperature of the cogenerator, which is turned on in order to keep the outlet temperature from the tank to $50{ }^{\circ} \mathrm{C}$.

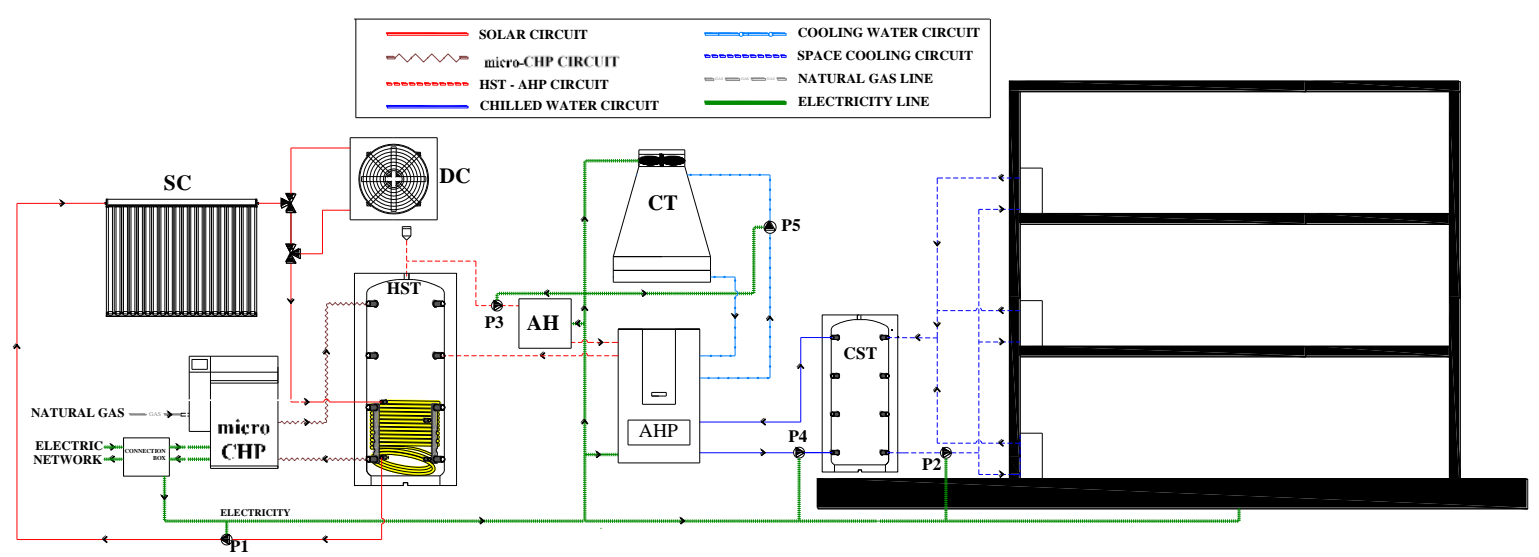

Figure 5. System configuration in cooling mode.

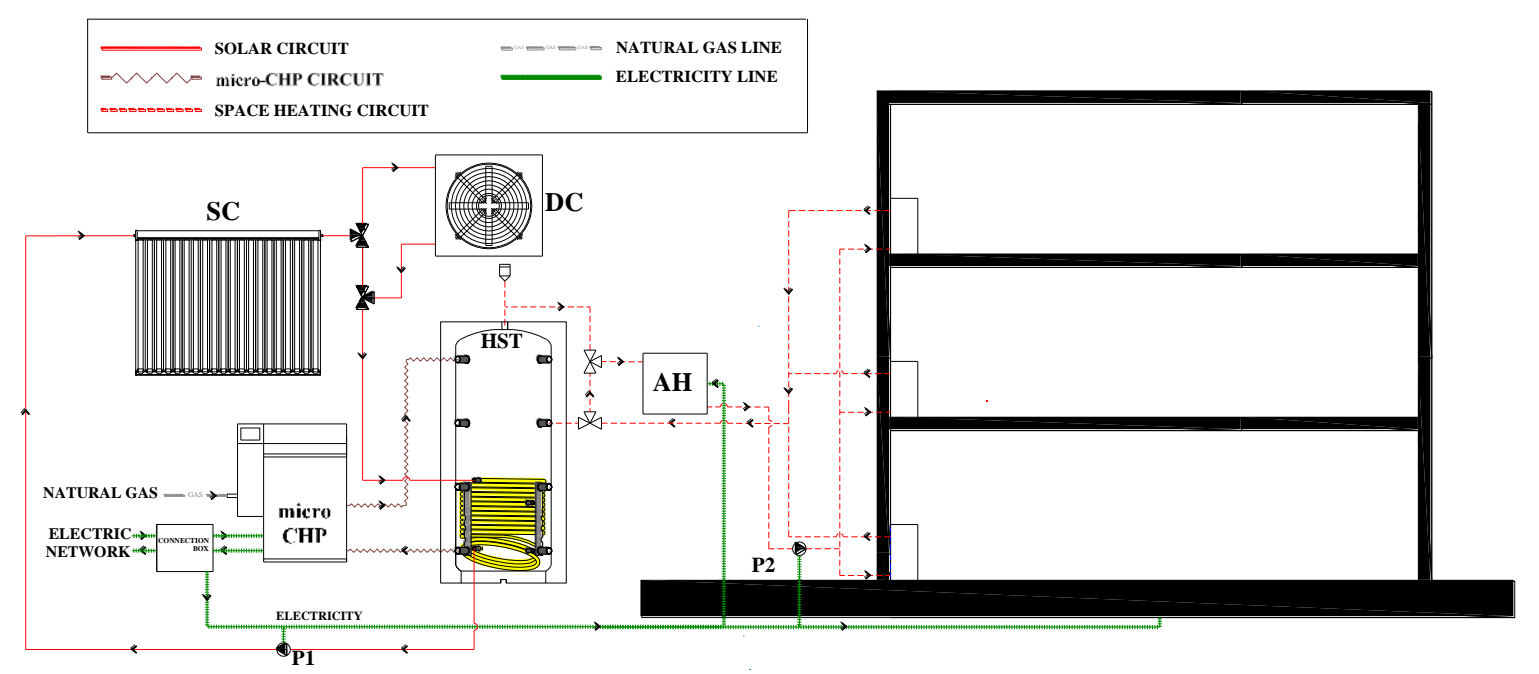

Figure 6. System configuration in heating mode.

As regards the second subsystem, during the cooling period, the AHP tries to maintain the temperature of a $500 \mathrm{~L} \mathrm{CST}$ in the range $9 \pm 1.5^{\circ} \mathrm{C}$ in the hours of the building opening. Indeed, it starts even when the building is closed and the micro-CHP is off but the HST is at a temperature that allows starting the absorption chiller. In this way, the system operates to maximize the accumulation of solar thermal energy and avoid its dissipation. The CT and the pumps P3, P4 and P5 are turned on simultaneously with the thermally-driven chiller (Figure 5).

In heating operation mode, instead, the AHP and the CST are bypassed by the hot water that is directly pumped to the fan coils of the offices. More in detail, a system of three-way valves diverts part of the heat transfer fluid that returns from the user and mixes it with the hot water of the tank to ensure that water at about $45^{\circ} \mathrm{C}$ is supplied to the fan coils. The AH is switched on only if the supply temperature decreases below $40{ }^{\circ} \mathrm{C}$ (Figure 6). 
A final control, that of the building subsystem, is then performed on the pump P2, that supplies hot/cold water to fan coils, to allow that the temperature of the air-conditioned spaces is equal to $20 \pm 0.5^{\circ} \mathrm{C}$ in winter and $26 \pm 0.5^{\circ} \mathrm{C}$ in summer period, respectively.

The electricity produced by the micro-CHP is mainly use to meet the electric load of the user and drives the auxiliaries of the plant. When the electricity production is low compared to the required amount, further electric energy is taken from the grid; instead, when the production exceeds the demand, the exceeding part is fed into the grid.

\section{Model Description}

In the following subsections, the models of the main components of the hybrid solar-assisted trigeneration system, used in the dynamic simulation software TRNSYS [12], are described. Each component model is a subroutines ("Type") stored in the standard and TESS (Thermal Energy Systems Specialists, Madison, WI, USA) library [29] of TRNSYS in many cases validated by experimental data. Unfortunately, these data have not been collected in such an experimental plant. Table 2 shows the devices and the corresponding simulation subroutine (Type).

Table 2. Hybrid solar-assisted trigeneration plant components and related TRNSYS types.

\begin{tabular}{ccc}
\hline Component & Type & Library \\
\hline Solar collectors & 71 & Standard \\
Cogenerator & 154 & IEA \\
Absorption heat pump & 107 & Standard \\
Hot Storage Tank & $60 \mathrm{f}$ & Standard \\
Cold Storage Tank & 534 & TESS \\
Cooling Tower & $51 \mathrm{~b}$ & Standard \\
\hline
\end{tabular}

\subsection{Solar Collectors}

The model is based on a quadratic equation of thermal efficiency of a solar collector, $\eta_{\text {th }}^{\text {SC }}$ (Equation (1)). In this equation, the three constant values $\eta_{0}, a_{1}$, and $a_{2}$ are typically provided by the manufacturer for defined test conditions. The temperature difference $(\Delta T)$ usually represents the difference between the average temperature of the fluid circulating in the collectors and the ambient air temperature [30], while $G$ is the total solar radiation on the tilted surface.

$$
\eta_{\mathrm{th}}^{\mathrm{SC}}=\eta_{0}-a_{1} \frac{\Delta T}{G}-a_{2} \frac{\Delta T^{2}}{G}
$$

The main parameters, taken from the manufacturer's data [27], used in TRNSYS are listed in Table 3. Furthermore, the model takes into account the correction due to the connection of the collectors in rows, to the operation with flowrate different from the test conditions and the incident radiation angle.

Table 3. Evacuated tube collectors parameters.

\begin{tabular}{ccc}
\hline Parameter & Value & Unit \\
\hline Specific heat capacity of the fluid & 3.84 & $\mathrm{~kJ} /(\mathrm{kg} \cdot \mathrm{K})$ \\
Tested flow rate & 30.4 & $\mathrm{~kg} /\left(\mathrm{h} \cdot \mathrm{m}^{2}\right)$ \\
Intercept efficiency $\eta_{0}$ & 0.676 & - \\
Efficiency slope $a_{1}$ & 1.15 & $\mathrm{~W} /\left(\mathrm{m}^{2} \cdot \mathrm{K}\right)$ \\
Efficiency curvature $a_{2}$ & 0.004 & $\mathrm{~W} /\left(\mathrm{m}^{2} \cdot \mathrm{K}^{2}\right)$ \\
Aperture area & 3.43 & $\mathrm{~m}^{2}$ \\
Gross area & 3.91 & $\mathrm{~m}^{2}$ \\
\hline
\end{tabular}


This correction for evacuated tube collectors, due to the symmetry of the system, is performed with two coefficients, known as Incident Angle Modifier (IAM) longitudinal and transversal. Table 4 shows these values for the considered collectors.

Table 4. Evacuated tube collectors incident angle modifier (IAM) factors.

\begin{tabular}{ccc}
\hline Direction $\left(^{\circ}\right)$ & Transversal IAM (-) & Longitudinal IAM (-) \\
\hline 0 & 1.00 & 1.00 \\
10 & 1.00 & 1.00 \\
20 & 1.00 & 1.00 \\
30 & 1.00 & 1.00 \\
40 & 1.03 & 0.98 \\
50 & 1.08 & 0.96 \\
60 & 1.15 & 0.87 \\
70 & 1.11 & 0.72 \\
80 & 0.72 & 0.50 \\
90 & 0.00 & 0.00 \\
\hline
\end{tabular}

\subsection{Micro Combined Heat and Power}

The micro-CHP model, developed within the International Energy Agency-Energy Conservation in Buildings and Community Systems (IEA/ECBCS) Annex 42, is implemented among others for the TRNSYS. The type is used to simulate a cogenerator with an internal combustion engine that provides thermal energy at a temperature compatible with the AHP. The 103 parameters characterizing the model are set according to the calibration and validation reported in [31].

The micro-CHP from the point of view of the model is discretized into three control volumes. The energy conversion control volume models the conversion of fuel chemical energy into electrical and thermal energy in steady conditions, therefore, it takes into account the engine working fluid, the combustion gases and the engine alternator. The dynamic behavior of the system is instead characterized through the two other control volumes, engine thermal mass control volume and cooling water volume control. They model the aggregate thermal mass of the engine and most internal heat exchanger equipment, the aggregate thermal mass of the cooling water and the portion of the exchanger in direct contact with the cooling fluid, respectively.

The electrical and thermal power under steady state conditions are calculated by scaling the primary power by two factors which are the electrical or thermal efficiency.

$$
\begin{aligned}
& \dot{E}_{e l}^{\text {micro-CHP }}=\eta_{e l}^{\text {micro-CHP }} \dot{m}_{\text {fuel }} L H V_{\text {fuel }} \\
& \dot{E}_{\text {th }}^{\text {micro-CHP }}=\eta_{\text {th }}^{\text {micro-CHP }} \dot{m}_{\text {fuel }} L H V_{\text {fuel }}
\end{aligned}
$$

The efficiencies are expressed by polynomial function $(f)$ of the electric power at steady-state $\left(\dot{E}_{\mathrm{el}}\right)$, the mass flow rate of cooling water $\left(\dot{m}_{\mathrm{cW}}\right)$, and the inlet temperature of the cooling water $\left(T_{\mathrm{cw}, \text { in }}\right)$.

$$
\begin{aligned}
& \eta_{\mathrm{el}}^{\text {micro-CHP }}=f\left(\dot{E}_{\mathrm{el}}, \dot{m}_{\mathrm{cw}}, T_{\mathrm{cw}, \text { in }}\right) \\
& \eta_{\mathrm{th}}^{\text {micro-CHP }}=f\left(\dot{E}_{\mathrm{el}}, \dot{m}_{\mathrm{cw}}, T_{\mathrm{cw}, \text { in }}\right)
\end{aligned}
$$

The dynamics are assessed by differential equations that take into account the combustion, the convective and conductive heat transfers and the mass exchanges. The model also takes into account a constraint on the maximum fuel flow rate and a protection for over-heating. The rated characteristics of the micro-CHP [32] are listed in the following Table 5. 
Table 5. Rated micro-CHP parameters.

\begin{tabular}{ccc}
\hline Parameter & Value & Unit \\
\hline Engine type & Reciprocating internal combustion engine, single cylinder, 4 stroke & - \\
Displacement & 580 & $\mathrm{~cm}^{3}$ \\
Fuel & Natural gas & - \\
Electric power & 5.50 & $\mathrm{~kW}$ \\
Thermal power & 12.5 & $\mathrm{~kW}$ \\
Electric efficiency & 26.8 & $\%$ \\
Thermal efficiency & 61.0 & $\%$ \\
\hline
\end{tabular}

\subsection{Storage Tank}

This model is developed for vertical cylindrical tanks; in fact, it considers the entire volume of the tank divided into smaller superimposed cylinders of equal height (called nodes). For each node (Figure 7), the temperature is considered uniform (fully-mixing of the liquid) and is numerically calculated by solving the set of energy balances of all the nodes. The generic equation to be solved has the following form:

$$
\begin{aligned}
& \left(m_{i} c_{p}\right) \frac{d T_{i}}{d \tau}=\frac{(k+\Delta k) A_{c, i}}{\Delta x_{i+1 \rightarrow i}}\left(T_{i+1}-T_{i}\right)+\frac{(k+\Delta k) A_{c, i}}{\Delta x_{i-1 \rightarrow i}}\left(T_{i-1}-T_{i}\right)+\left(U_{\tan k}+\Delta U_{i}\right) A_{s, i}\left(T_{\text {env }}-T_{i}\right)+\dot{m}_{\text {down }} c_{p} T_{i-1} \\
& -\dot{m}_{u p} c_{p} T_{i}-\dot{m}_{\text {down }} c_{p} T_{i}-\dot{m}_{u p} c_{p} T_{i+1}+U A_{h x 1} \Delta T_{\ln 1}+U A_{h x 2} \Delta T_{\ln 2}+U A_{h x 3} \Delta T_{\ln 3}+\dot{m}_{1 \text { in }} c_{p} T_{1 \text { in }}-\dot{m}_{1 \text { out }} c_{p} T_{i} \\
& +\dot{m}_{2 \text { in }} c_{p} T_{2} T_{\text {in }}-\dot{m}_{2 \text { out }} c_{p} T_{i}
\end{aligned}
$$

where the terms, from left to right, in the equation represent: the energy variation in the node per unit of time, the conductive heat exchange between the considered node and the upper and lower one, the heat losses, the convective interaction of the node (the terms related to $\dot{m}_{\text {up }}, \dot{m}_{\text {down }}, \dot{m}_{\text {in }}$ and $\dot{m}_{\text {out }}$ ) and finally the contributions of the exchangers.

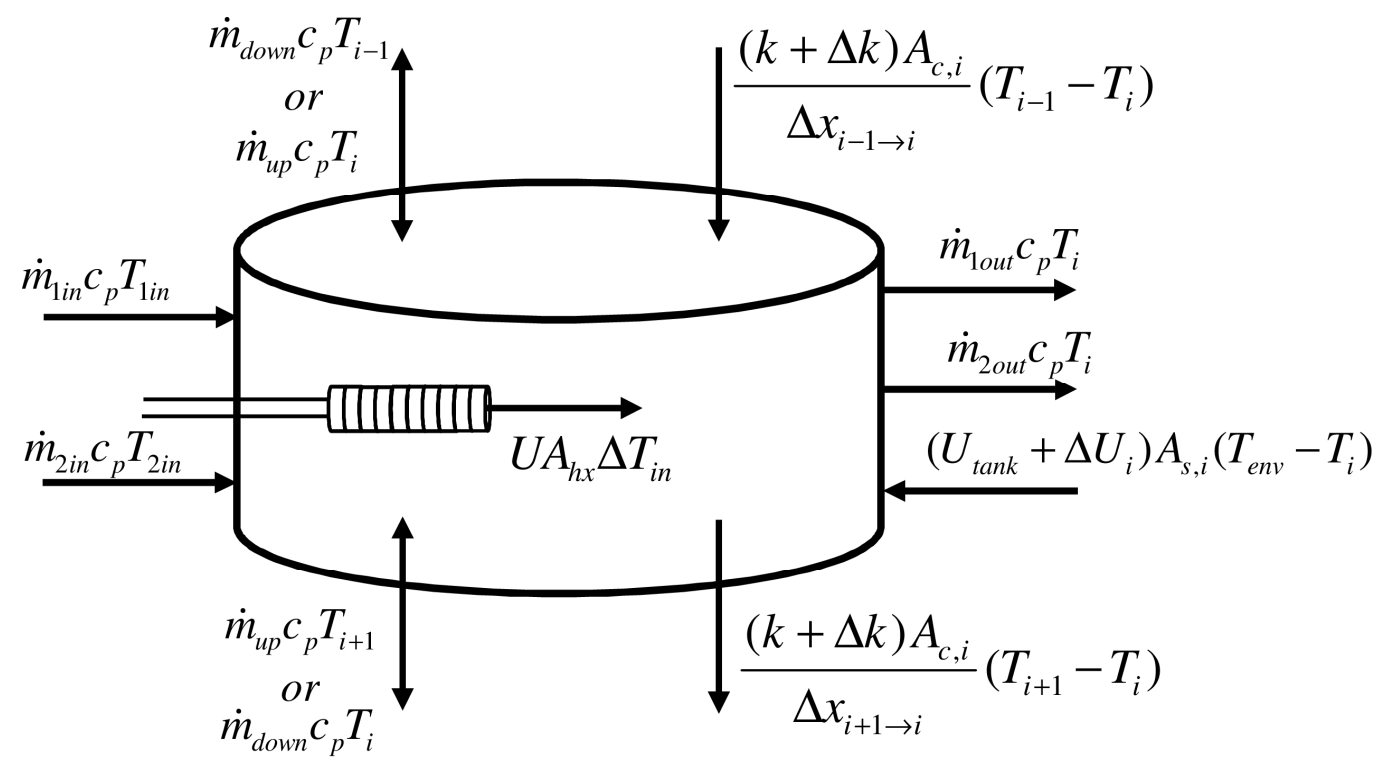

Figure 7. Generic node of a detailed stratified tank storage.

For the hot water storage, the data validated and calibrated by Angrisani et al. [33] are assumed, while for the cold water storage manufacturer information is considered [34]. A summary of the parameters of the model and of the data sheet information is listed in Table 6. The model of the CST is based on the same equations described for the HST. 
Table 6. Cold water storage tank (CST) parameters.

\begin{tabular}{ccc}
\hline Parameter & Value & Unit \\
\hline Number of tank nodes & 20 & - \\
Number of inlets and outlets & $2+2$ & - \\
Tank volume & 0.5 & $\mathrm{~m}^{3}$ \\
Tank height & 1.5 & $\mathrm{~m}$ \\
Thermal loss coefficient & 0.77 & $\mathrm{~W} /\left(\mathrm{m}^{2} \cdot \mathrm{K}\right)$ \\
\hline
\end{tabular}

\subsection{Absorption Heat Pump}

The hot water-driven AHP model is based on a performance map that can typically be found in manufacturers' catalogs. Figure 8 shows the cooling capacity and the heat input of the AHP considered in this work as a function of the heat source and cooling water temperature. In particular, the machine performance are reported in terms of fraction of full load capacity and fraction of design heating energy for different operating conditions (fraction of the design load, chilled water set point temperature, entering cooling and hot water temperatures). On the basis of the conditions that take place at each simulation step, the model determines the heating energy required $\left(\dot{E}_{\mathrm{th}, \text { req }}^{\mathrm{AHP}}\right)$ by the AHP, its cooling capacity available $\left(\dot{E}_{\mathrm{co}, \mathrm{ava}}^{\mathrm{AHP}}\right)$ and that needed to cool down the entering chilled water to the set point temperature $\left(\dot{E}_{\mathrm{co}, \mathrm{Aeq}}^{\mathrm{AHP}}\right)$. The temperature of the chilled water exiting the AHP is calculated by considering the lower cooling capacity between the available one and that required:

$$
T_{\mathrm{chw}, \text { out }}=T_{\mathrm{chw}, \text { in }}-\frac{\min \left(\dot{E}_{\mathrm{co,ava},}^{\mathrm{AHP}}, \dot{E}_{\mathrm{co}, \text { req }}^{\mathrm{AHP}}\right)}{\dot{m}_{\mathrm{chw}} c_{\mathrm{p}, \mathrm{chw}}}
$$

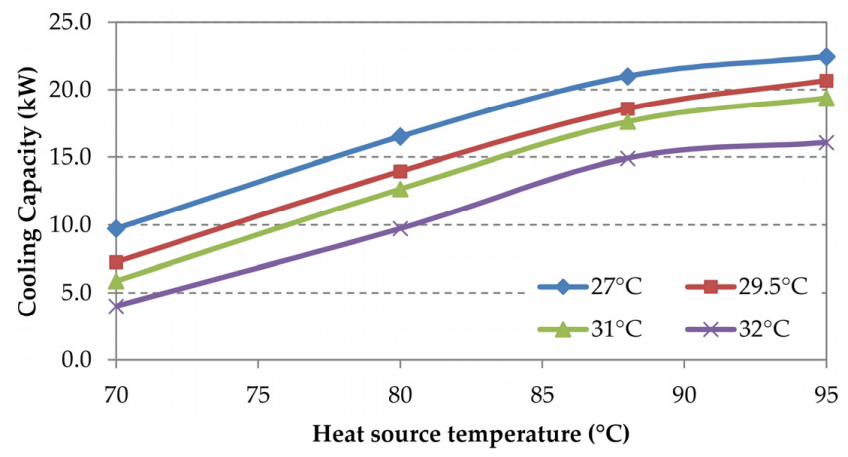

(a)

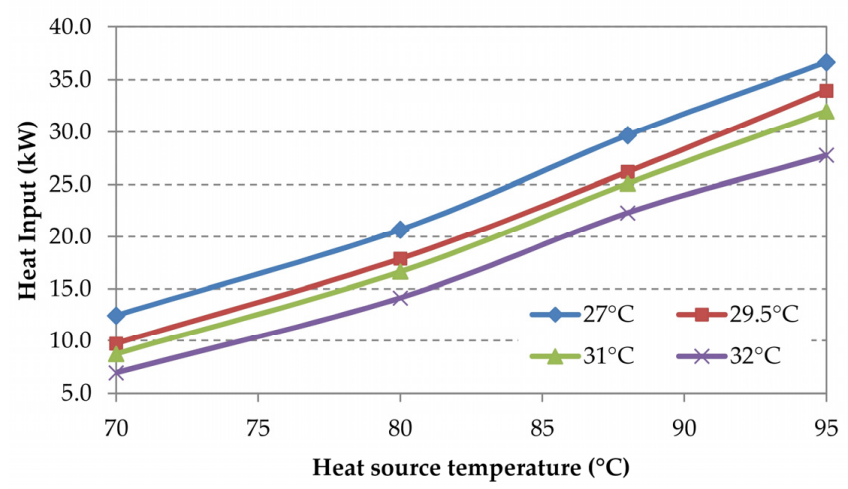

(b)

Figure 8. Cooling capacity (a) and heat input (b) of the considered AHP as a function of the heat source and cooling water temperature. 
The energy rejected by the cooling water (CT) is determined with an energy balance on the absorption chiller also taking into account the energy of the auxiliary devices. The temperatures of the hot and cooling water at the AHP outlets are, instead, evaluated through energy balances on the cooling and heating water flows. The rated characteristics of the selected AHP are listed in Table 7 [29].

Table 7. AHP nominal characteristics.

\begin{tabular}{ccc}
\hline Rated Parameter & Value & Unit \\
\hline Cooling capacity & 17.6 & $\mathrm{~kW}$ \\
Chilled water flow rate & 2.77 & $\mathrm{~m}^{3} / \mathrm{h}$ \\
Chilled water temperature & $12.5-7.00$ (inlet-outlet) & ${ }^{\circ} \mathrm{C}$ \\
Heat rejection & 42.7 & $\mathrm{~kW}$ \\
Cooling water flow rate & 9.18 & $\mathrm{~m}^{3} / \mathrm{h}$ \\
Cooling water temperature & $31-35$ (inlet-outlet) & ${ }^{\circ} \mathrm{C}$ \\
Heat input & 25.1 & $\mathrm{~kW}$ \\
Heating water flow rate & 4.32 & $\mathrm{~m}^{3} / \mathrm{h}$ \\
Heating water temperature & $88-83$ (inlet-outlet) & ${ }^{\circ} \mathrm{C}$ \\
Electric power ${ }^{1}$ & 0.048 & $\mathrm{~kW}$ \\
Coefficient of Performance (COP) & 0.70 & - \\
\hline
\end{tabular}

${ }^{1}$ It takes into account only the internal electric demands of the AHP. The pumps and the cooling tower (CT) demands are excluded.

\subsection{Cooling Tower}

The cooling process of the AHP cooling water takes place in the CT as a result of the sensible heat transfer and the evaporation of the water towards the air. Typically, the water to be cooled is sprayed (in counter-flow) at the top of the CT, while the air is moved by a fan from the bottom to the top of the tower. Typically a CT is filled with a material, organized in cells, able to increase the contact area between water and air.

"Type 51" is here considered to model the performance of a multiple-cell CT. The thermal power subtracted to the water in a cell can be expressed as a function of the maximum one (the air exits at the inlet water temperature and in saturated conditions) through the efficiency $\varepsilon$ :

$$
\dot{E}_{\text {cell }}=\varepsilon \dot{m}_{\mathrm{a}}\left(h_{\mathrm{a}, \mathrm{sat}}\left(T_{\mathrm{cw}, \text { in }}\right)-h_{\mathrm{a}, \text { in }}\right)
$$

the CT performance $(\varepsilon)$, assuming the Lewis number equal to 1 , can be expressed through a mathematical model that uses the approach of the number of transfer units (NTU), as for the only sensible heat exchange. In this case of heat and mass transfer, NTU is equal to [35]:

$$
N T U=\frac{K^{\prime} a V_{\text {cell }}}{\dot{m}_{\mathrm{a}}}
$$

where $K^{\prime}$ is the mass transfer coefficient, $a$ is the water surface per unit volume, $V_{\text {cell }}$ is the cell cooling volume, and $\dot{m}_{\mathrm{a}}$ is the mass flow rate of air.

Correlation between NTU and the air and water flowrates has the following form:

$$
N T U=\mathrm{c}\left(\frac{\dot{\mathrm{m}}_{\mathrm{cw}}}{\dot{\mathrm{m}}_{\mathrm{a}}}\right)^{1+\mathrm{n}}
$$

the two coefficients $c$ and $n$ change according to the differ CT type [36]. The values listed in Table 8 are assumed to characterize the CT. Finally, overall energy and mass balances allow evaluating the fluids conditions at the tower output. 
Table 8. Cooling tower (CT) parameters.

\begin{tabular}{ccc}
\hline Parameter & Value & Unit \\
\hline Number of tower cells & 1 & - \\
Maximum cell flow rate & 4300 & $\mathrm{~m}^{3} / \mathrm{h}$ \\
Fan power at maximum flow & 0.55 & $\mathrm{~kW}$ \\
Sump volume & 0.06 & $\mathrm{~m}^{3}$ \\
Initial sump temperature & 15 & ${ }^{\circ} \mathrm{C}$ \\
Mass transfer constant & 1.36 & - \\
Mass transfer exponent & -0.94 & - \\
\hline
\end{tabular}

\section{Results and Discussion}

The software TRNSYS with TESS libraries has been used to perform the dynamic simulation of the hybrid solar-assisted trigeneration system and the building described before.

As a first analysis, the influence of the collectors tilt angle on the $S F$ [37] has been investigated. It is calculated as the ratio between the thermal energy satisfied by renewable source, $\mathrm{SC},\left(E_{\mathrm{th}, \mathrm{Hen}, \mathrm{hp}}^{H S T}\right)$ and the total heat demand of the user $\left(E_{\mathrm{th}}^{\mathrm{US}}\right)$ :

$$
S F_{\mathrm{hp}}=\frac{E_{\mathrm{th}, \mathrm{ren}, \mathrm{hp}}^{\mathrm{HST}}}{E_{\mathrm{th}}^{\mathrm{US}}}
$$

For the heating operation period, it shows an increasing trend with higher tilt angles (Figure 9a). The same index, evaluated for the cooling operation period, is defined as:

$$
S F_{\mathrm{cp}}=\frac{E_{\mathrm{co}, \mathrm{ren}}^{\mathrm{CST}}}{E_{\mathrm{co}}^{\mathrm{US}}}
$$

where $E_{\mathrm{co}, \text { ren }}^{\mathrm{CST}}$ is the contribution of cooling energy supplied by the CST during the cooling operation period deriving from the solar thermal energy. The $S F_{\mathrm{cp}}$ shows an opposite trend with respect to $S F_{\mathrm{hp}}$, it worsens when the tilt angle increases (Figure 9a). The trade-off between these two trends results in a total $S F\left(S F_{\text {tot }}\right)$ on an annual basis with a maximum for a tilt angle of about $30^{\circ}$ (Figure $9 \mathrm{~b}$ ).

$$
S F_{\text {tot }}=\frac{E_{\mathrm{th}, \mathrm{ren}, \mathrm{hp}}^{\mathrm{HST}}+E_{\mathrm{co}, \mathrm{ren}}^{\mathrm{CST}}}{E_{\mathrm{th}}^{\mathrm{US}}+E_{\mathrm{co}}^{\mathrm{US}}}
$$

Considering the plant optimized with respect to the total $S F$, the energy flows related to the heating period and those related to the cooling period are listed in the Table 9.

In heating mode, the results highlight that the SC have an average efficiency of $44.2 \%$, while the micro-CHP has an electrical and thermal efficiency of $25.5 \%$ and $63.2 \%$, respectively. The tank has significant thermal losses, amounting to $19.5 \%$ of the thermal energy supplied. The thermal load is almost completely met by the energy supplied by the HST, the amount of heat of the AH is very small (35.4 kWh).

As regards the electric energy, the greatest demand derives from the user pure electric load ( $92.4 \%$ of the total demand derives from lighting, computers, printers, etc.). The remaining part is due to the auxiliaries $E_{\mathrm{el}, \mathrm{hp}}^{\mathrm{AUX}}$ and is mainly attributable to the circulating pumps of solar and heating subsystems $\left(E_{\mathrm{el}, \mathrm{hp}}^{P 1}=26.8 \%\right.$ of $E_{\mathrm{el}, \mathrm{hp}}^{\mathrm{AUX}}, E_{\mathrm{el}, \mathrm{hp}}^{P 2}=49.7 \%$ of $\left.E_{\mathrm{el}, \mathrm{hp}}^{\mathrm{AUX}}\right)$. 


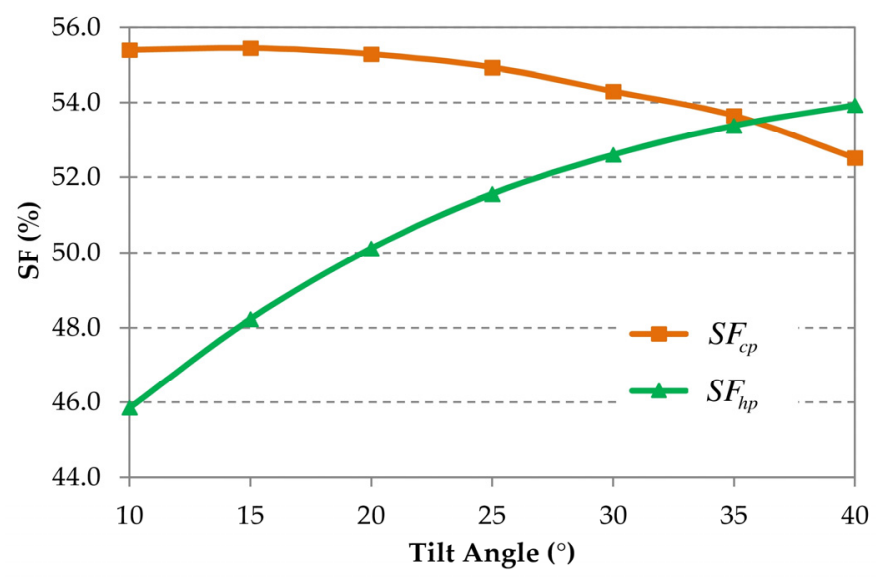

(a)

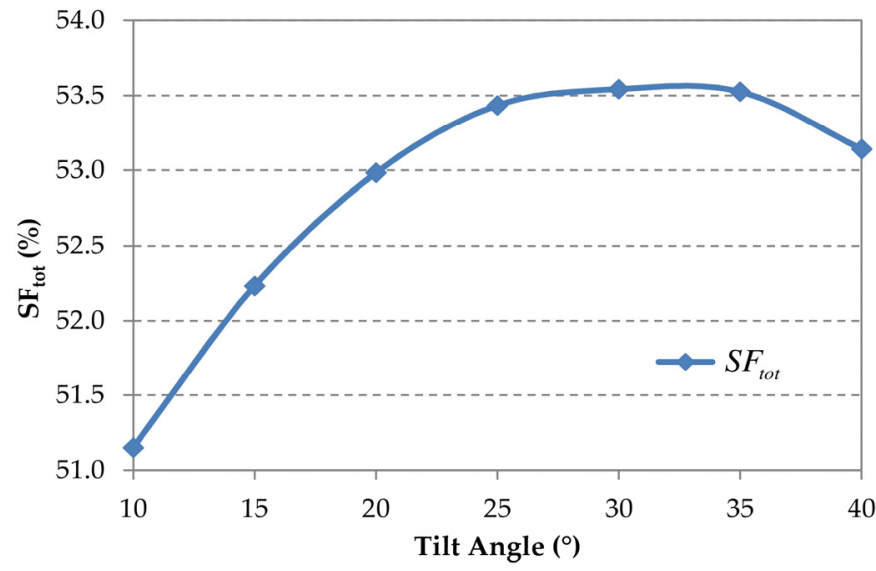

(b)

Figure 9. (a) Seasonal and (b) total solar fractions (SFs) as a function of tilt angle.

Table 9. Heating and cooling operation energy flows.

\begin{tabular}{|c|c|c|c|}
\hline Components & Energy Flows & $\begin{array}{c}\text { Heating Operation } \\
(\mathrm{MWh} / \mathrm{y})\end{array}$ & $\begin{array}{c}\text { Cooling Operation } \\
(\mathrm{MWh} / \mathrm{y})\end{array}$ \\
\hline \multirow{2}{*}{ SC } & Solar energy (total) on tilted surface & 7.87 & 15.2 \\
\hline & Solar thermal energy by SC & 3.48 & 7.83 \\
\hline DC & Solar thermal energy dissipated by DC & $4.88 \times 10^{-1}$ & 2.00 \\
\hline \multirow{3}{*}{ Micro-CHP } & Primary energy required by micro-CHP & 4.36 & 7.19 \\
\hline & Thermal energy supplied by the micro-CHP & 2.76 & 4.39 \\
\hline & Electric energy produced by micro-CHP & 1.11 & 1.87 \\
\hline \multirow{2}{*}{ HST } & Thermal energy supplied to the HST & 5.89 & 10.5 \\
\hline & Thermal energy supplied by the HST & 4.74 & 9.09 \\
\hline $\mathrm{AH}$ & Thermal energy supplied by the AH & $3.54 \times 10^{-2}$ & 0.64 \\
\hline \multirow{2}{*}{ AHP } & Thermal energy supplied to the AHP & - & 9.73 \\
\hline & Cooling energy AHP & - & 6.04 \\
\hline $\mathrm{CT}$ & Thermal energy rejected by CT & - & 15.8 \\
\hline \multirow{2}{*}{ CST } & Thermal energy removed by AHP & - & 6.04 \\
\hline & Thermal energy received by US & - & 5.95 \\
\hline AUX & Electric energy required by the AUX & $3.98 \times 10^{-1}$ & 1.31 \\
\hline \multirow{2}{*}{ US } & Cooling load & 4.79 & 5.95 \\
\hline & Electric load & 4.80 & 4.27 \\
\hline \multirow[b]{2}{*}{ GRID } & Electric energy fed into the grid & $3.97 \times 10^{-1}$ & 0.37 \\
\hline & Electric energy taken from the grid & 4.49 & 4.08 \\
\hline
\end{tabular}


In cooling operation mode, the results show that the SC have an average efficiency of $51.5 \%$, while the micro-CHP has an electric and thermal efficiency of $26.0 \%$ and $61.0 \%$, respectively. The HST has significant thermal losses, amounting to $13.4 \%$. The cooling load is met by the chilled water supplied by the CST, which interacts with the warmer air surrounding it (about $95 \mathrm{kWh}$ ). The AHP cools down the water in the CST, operating with a coefficient of performance (evaluated as the ratio between the cooling energy supplied and the thermal energy required in the entire cooling period) equal to 0.62 .

As regards the electric energy the greatest demand derives from the user pure electric load (76.5\% of the total) while the remaining part is due to the auxiliaries $\left(E_{\mathrm{el}, \mathrm{cp}}^{\mathrm{AUX}}\right)$, and is mainly attributable to the $\mathrm{AH}$, the $\mathrm{AHP}$ and $\mathrm{CT}$, the circulating pumps of solar and distribution subsystems $\left(E_{\mathrm{el}, \mathrm{cp}}^{\mathrm{AH}}=48.9 \%\right.$ of $E_{\mathrm{el}, \mathrm{cp}}^{\mathrm{AUX}}, E_{\mathrm{el}, \mathrm{cp}}^{\mathrm{AHACT}}=15.7 \%$ of $E_{\mathrm{el}, \mathrm{cp}}^{\mathrm{AUX}}, E_{\mathrm{el}, \mathrm{cp}}^{P 1}=19.5 \%$ of $E_{\mathrm{el}, \mathrm{cp}}^{\mathrm{AUX}}, E_{\mathrm{el}, \mathrm{cp}}^{P 2}=9.47 \%$ of $E_{\mathrm{el}, \mathrm{cp}}^{\mathrm{AUX}}$ ).

Figure 10 highlights that the electric energy contribution supplied by the grid during the heating period $\left(E_{\mathrm{el}, \mathrm{GL}}^{\mathrm{GRD}}\right)$ is very high, achieving $93.5 \%$ of the total consumed. As concerns the micro-CHP, 36\% of the electric energy produced is exported to the grid ( $\left.E_{\mathrm{el}, \mathrm{exp}, \mathrm{mp}}^{\mathrm{micr}-\mathrm{CHP}}\right)$ while the remaining $64 \%\left(E_{\mathrm{el}, \mathrm{sc}, \mathrm{hp}}^{\mathrm{MCHP}}\right)$ is self-consumed in the building-plant system.

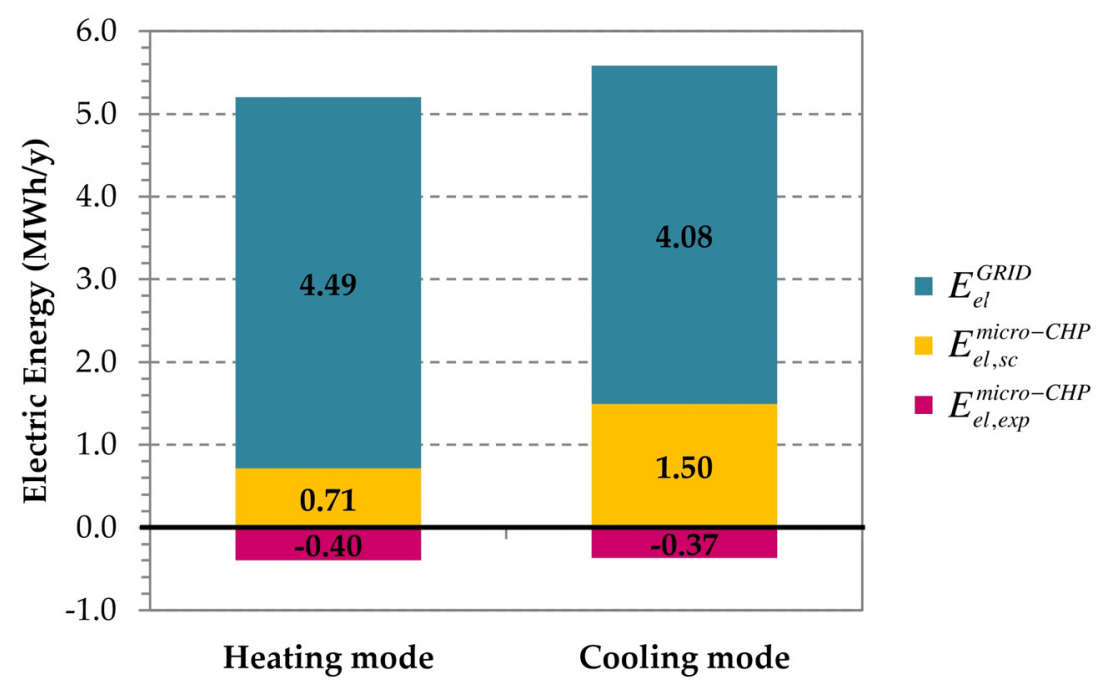

Figure 10. Electric energy flows.

The electric energy supplied by grid in the cooling period, $\left(E_{\mathrm{el}, \mathrm{GR}}^{\mathrm{GRID}}\right)$, is again greater than that produced by the micro-CHP. The cogeneration system exports $371 \mathrm{kWh}\left(E_{\mathrm{el}, \mathrm{sc}, \mathrm{Mp}}^{\mathrm{MCHP}}\right)$ that represents $19.8 \%$ of the total available. The amount of micro-CHP electric energy used in the building is greater than in the heating period $(80.2 \%)$.

Taking into account the primary energy required by micro-CHP in the two operation mode, the electric and thermal energy supplied, the cogenerator shows an electric and thermal efficiency, on an annual basis, equal to $25.8 \%$ and $61.9 \%$, respectively (Table 9 ).

The Sankey diagrams in Figure 11a, b show how the total primary energy of the solar source and of the natural gas required by the micro-CHP are converted to meet the cooling and heating demands of the building. As mentioned before, most of the electricity demands are due to the user load and only a small share is supplied to the plant, so the electricity supplied by the external grid has been neglected.

A large amount of the incident solar energy is not converted both in summer and winter. The greater availability of solar energy in the summer lead to a low contribution of the micro-CHP $\left(E_{\mathrm{th}, \mathrm{cp}}^{\text {micro-CHP }}\right)$ if compared to solar one $\left(E_{\mathrm{th}, \mathrm{cp}}^{\mathrm{SC}-\mathrm{HST}}\right)$, while in winter these two terms are very similar.

During the summer, there is greater availability of solar energy and the total energy input to the system is more significant than in winter. In addition, a greater amount of solar thermal energy is dissipated in summer. However, because of the major number of energy conversion (and storage) 
devices, the useful effect (conditioned space cooling) is lower in percentage with respect to the offices heating requirements (26.5\% instead of $39.1 \%)$.

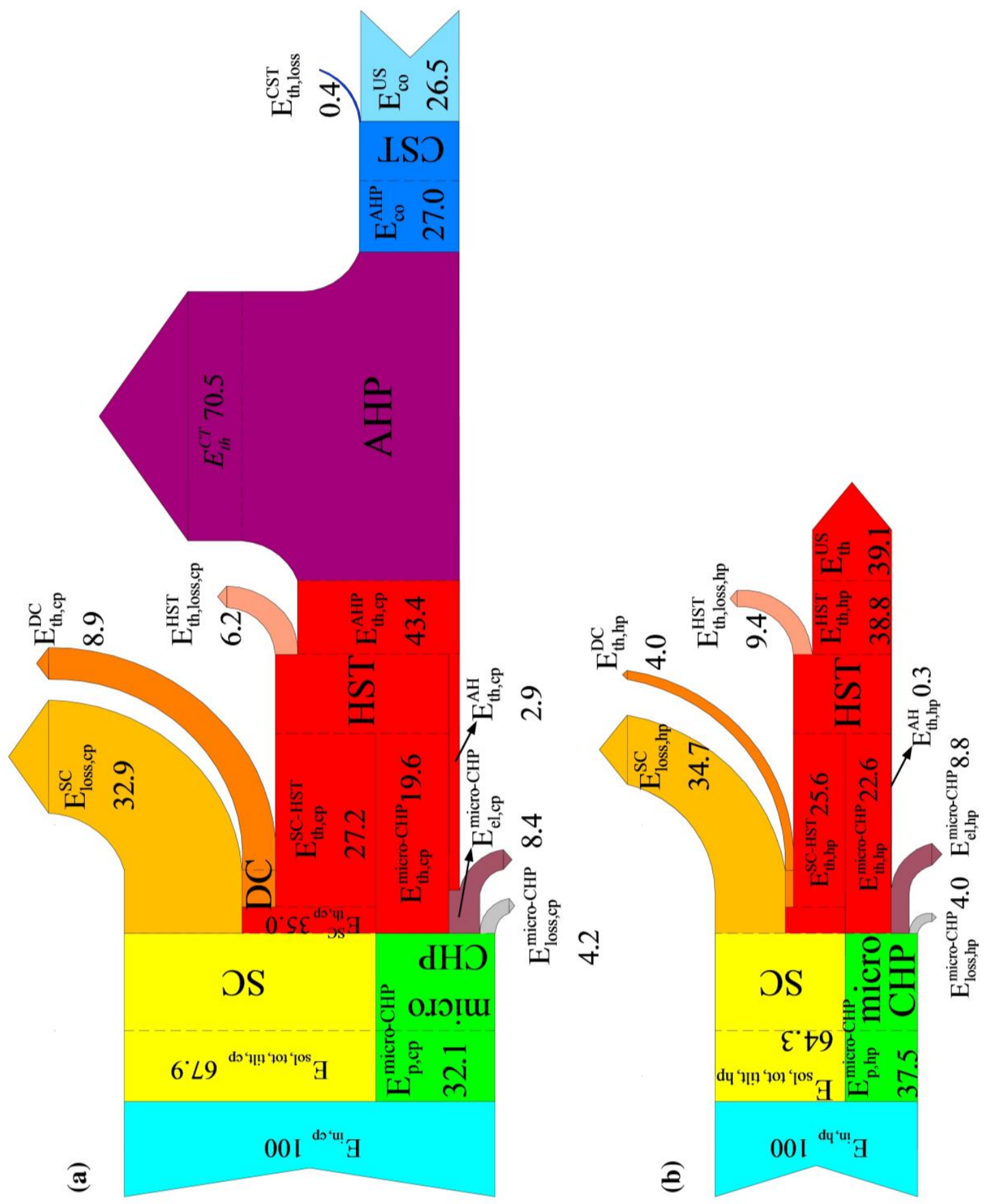

Figure 11. Sankey diagrams for (a) cooling and (b) heating operation.

The thermal losses through the HST envelope are not negligible and, in absolute terms, they are higher during the cooling period (1.41 MWh) than in the heating season (1.15 MWh) since there is an average higher temperature difference between the stored hot water and the environmental conditions in cooling operation with respect to the heating. If one considers the ratio between thermal losses and heat inputs to the HST, the winter result (0.195) is higher than that observed in summer (0.134). This is due to: 
(1) a longer heating period but a lower thermal energy demand (with respect to cooling season); and

(2) longer periods (in heating operation) during which the thermal energy stored in the HST is not used (in the summer period the AHP can operate also in the weekend days to cool down the CST.

These losses lead to a greater use of the micro-CHP and a lower solar energy exploitation in the described plant. For this reason, three new tanks [34] are simulated and compared with the HST considered in the previous analyses (Table 10).

Table 10. Main characteristics of the considered hot water tanks.

\begin{tabular}{|c|c|c|c|}
\hline Tank & Net Volume (L) & Height (m) & Thermal Losses Coefficient $\left(\mathrm{W} /\left(\mathrm{m}^{2} \cdot \mathrm{K}\right)\right)$ \\
\hline $1000[33]$ & 971 & 2.04 & 1.37 \\
\hline 1000 new [34] & 926 & 2.04 & 0.673 \\
\hline $1500[34]$ & 1409 & 2.04 & 0.673 \\
\hline $2000[34]$ & 1942 & 2.04 & 0.673 \\
\hline
\end{tabular}

The first new HST has the same volume but a lower loss coefficient $\left(0.673 \mathrm{~W} /\left(\mathrm{m}^{2} \cdot \mathrm{K}\right)\right)$ than that used before, instead the second and third ones have the same thermal characteristics of the new tank but bigger volume equal to $1500 \mathrm{~L}$ and $2000 \mathrm{~L}$, respectively.

Analyzing the $S F_{\text {tot }}$ (Figure 12a), it is noted that this index enhances with the new tank and increasing the storage volume. Instead in terms of thermal losses (in Figure 12b, they are expressed as a percentage of the thermal energy supplied to the tank and are reported with negative values in order to highlight that they are undesirable), it is shown that the best solution is constituted by the new 1000 L tank. Evidently, increasing the tank volume the solar thermal energy storage capacity increases (and thus $S F_{\text {tot }}$ improves) but the surface and the losses grow more.

Finally, by comparing the analyzed trigeneration plant with a similar SHC system in which the micro-CHP is replaced by a natural gas fired boiler and the electricity is drawn entirely from the grid a significant primary energy savings is achieved. Assuming an average efficiency of the Italian thermoelectric plants and boilers of 0.409 and 0.902 , respectively, it results a primary energy savings of $8.27 \%$. From an economic point of view, the cogenerator has an extra cost of about 15,000 $€$ and estimating the unitary price of electricity $0.20 € / \mathrm{kWh}$ if taken from the grid and $0.09 € / \mathrm{kWh}$ if fed into the grid, with a natural gas unitary price of $0.90 € / \mathrm{Nm}^{3}\left(0.75 € / \mathrm{Nm}^{3}\right.$ if defiscalized for cogeneration) an operating cost saving of about $286 € / y$ is reached. It is too low to have an acceptable pay back period. Therefore, the analyzed solution seems more advantageous than a conventional SHC system with a boiler but economically unfeasible.

The hybrid solar-assisted trigeneration system based on micro-CHP coupled to solar thermal collectors shows also a certain primary energy saving $(7.77 \%)$ with respect to the conventional air conditioning system used in Italy, that consists of a natural gas fired boiler for the heating operation and an electric chiller for the cooling (average $C O P=3.00$ ). However an operating cost saving of $230 € / y$ is related to this primary energy saving. It is very low compared to the extra cost of the hybrid plant, about $48,000 €$. If one considers the system with the better insulated 1000 L HST primary energy and operating costs savings go up at $9.34 \%$ and about $275 € / y$, respectively. The economic feasibility remains unthinkable if the investment costs for these new technologies do not decrease and the more efficient electricity and heat production (especially when renewable energy sources are used) is adequately supported from an economic point of view. It is at the same time true that the application of these systems to users that allow a greater number of hours of operation per year would significantly improve the benefits. 


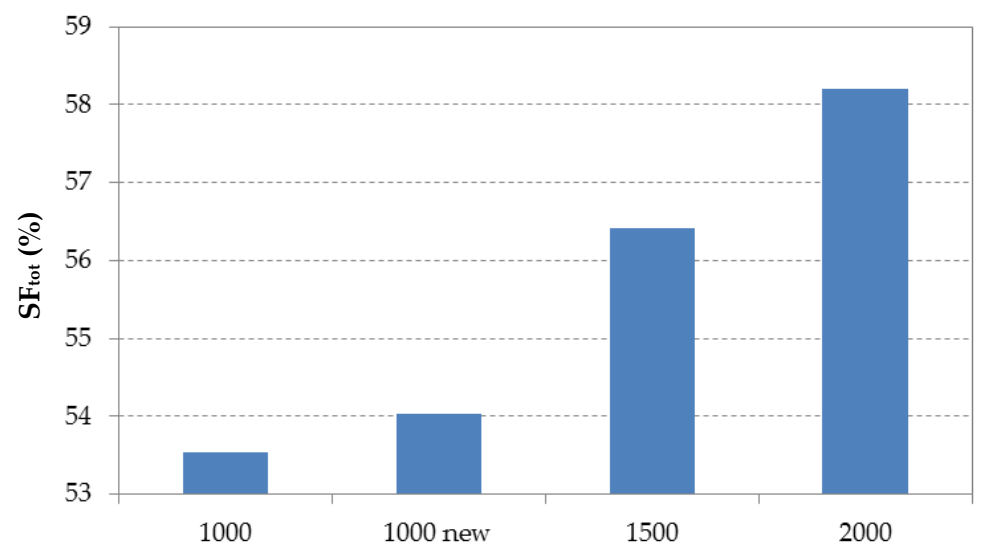

Storage volume and type of HST

(a)

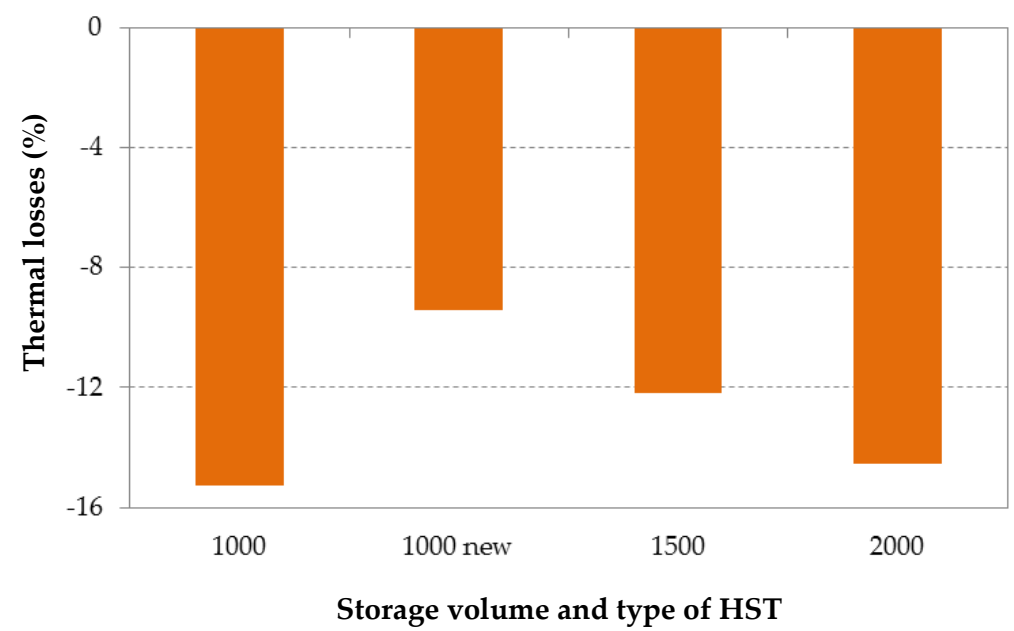

(b)

Figure 12. SF (a) and thermal losses (b) as a function of the storage tank.

\section{Conclusions}

In this paper, a plant designed to meet electricity, thermal and cooling demand of a three-story office building located in Naples, has been investigated. The installation is based on a natural gas fueled micro-CHP, solar thermal collectors and an absorption chiller. Such a hybrid solar-assisted trigeneration system is equipped with hot and cold storage tanks and an electric $\mathrm{AH}$ as back-up device, in order to compensate the uncertainty of solar source. Its control strategy ensures that the solar subsystem operates in priority and the micro-CHP is off during weekend days in heating and cooling operation.

The dynamic building-plant performance has been investigated using the software TRNSYS.

The results show that in the heating operation period the SF has an increasing trend with higher tilt angles, instead in cooling mode, this index has the opposite behavior. The trade-off between the two trends results in a total $S F$ with a maximum for a tilt angle of about $30^{\circ}$. After the optimization of the plant with respect to the collectors tilt angle, the energy flows in winter and summer period have been evaluated too.

The SC have a net efficiency of about $49 \%$. The micro-CHP has an electric efficiency of about $25.8 \%$ both in heating and cooling operation, while it has a thermal efficiency greater than $60 \%$. The HST has significant thermal losses amounting to $19.5 \%$ and $13.4 \%$ during heating and cooling operation mode, respectively. Concerning the interaction with the electric grid, the energy drawn from it is greater than the cogenerated electricity both in heating and cooling period. 
Finally, three different HST have been considered to highlight the influence of storage tank characteristics (thermal resistance and volume) on dynamic performance of the system. In the first scenario, a tank with the same volume and a lower loss coefficient with respect to the base case has been considered, while in the second and third layout two storage tanks with a bigger volume $(1500 \mathrm{~L}$ and $2000 \mathrm{~L}$ ) have been investigated.

The analysis has demonstrated that the $S F$ increases with the storage volume and the lowest thermal losses are achieved by $1000 \mathrm{~L}$ thermal storage with the lower loss coefficient.

Author Contributions: All authors have transversal expertise on the main topics of this paper, and they jointly shared the structure and aims of the manuscript. More specifically, Elisa Marrasso dealt more with literature review and building description. Carlo Roselli and Francesco Tariello dealt more with the modeling and simulation, and Maurizio Sasso contributed more to the results analysis. Finally, all authors equally contributed during the writing and the critical revision of the paper, according to the reviewers' comments.

Conflicts of Interest: The authors declare no conflict of interest.

\section{Nomenclature}

$\begin{array}{ll}A & \text { Area }\left(\mathrm{m}^{2}\right) \\ a & \text { Water surface per unit volume }\left(\mathrm{m}^{2} / \mathrm{m}^{3}\right) \\ a_{1} & \text { Efficiency slope }\left(\mathrm{W} / \mathrm{m}^{2} \cdot \mathrm{K}\right) \\ a_{2} & \text { Efficiency curvature }\left(\mathrm{W} / \mathrm{m}^{2} \cdot \mathrm{K}\right) \\ c & \text { Mass transfer constant }(-) \\ c_{p} & \text { Water specific heat }(\mathrm{kJ} / \mathrm{kg} \cdot \mathrm{K}) \\ \dot{E} & \text { Power }(\mathrm{kW}) \\ f & \text { Polynomial function } \\ g & \text { Total solar energy transmittance }(\text { or solar heat gain coefficient })(-) \\ G & \text { Total solar radiation on the tilted surface }\left(\mathrm{kW} / \mathrm{m}^{2}\right) \\ h & \text { Specific enthalpy }(\mathrm{kJ} / \mathrm{kg}) \\ H D D & \text { Heating degree day }\left({ }^{\circ} \mathrm{C}\right) \\ k & \text { Water thermal conductivity }(\mathrm{W} / \mathrm{m} \cdot \mathrm{K}) \\ K^{\prime} & \text { Mass transfer coefficient }\left(\mathrm{kg} /\left(\mathrm{s} \cdot \mathrm{m}^{2}\right)\right) \\ L H V & \text { Lower Heating Value }(\mathrm{kWh} / \mathrm{kg}) \\ \dot{m} & \text { Mass flow rate }(\mathrm{kg} / \mathrm{h}),(\mathrm{kg} / \mathrm{s}) \\ m & \text { Mass }(\mathrm{kg}) \\ n & \text { Mass transfer exponent }(-) \\ N T U & \text { Number of Transfer Units }(-) \\ S F & \text { Solar fraction }(\%) \\ T & \text { Temperature }(\mathrm{K}),\left({ }^{\circ} \mathrm{C}\right) \\ U & \text { Overall heat transfer coefficient for thermal losses }\left(\mathrm{W} / \mathrm{m}^{2} \cdot \mathrm{K}\right) \\ \mathrm{V} & \text { Volume }\left(\mathrm{m}^{3}\right)\end{array}$

\section{Greek Symbols}

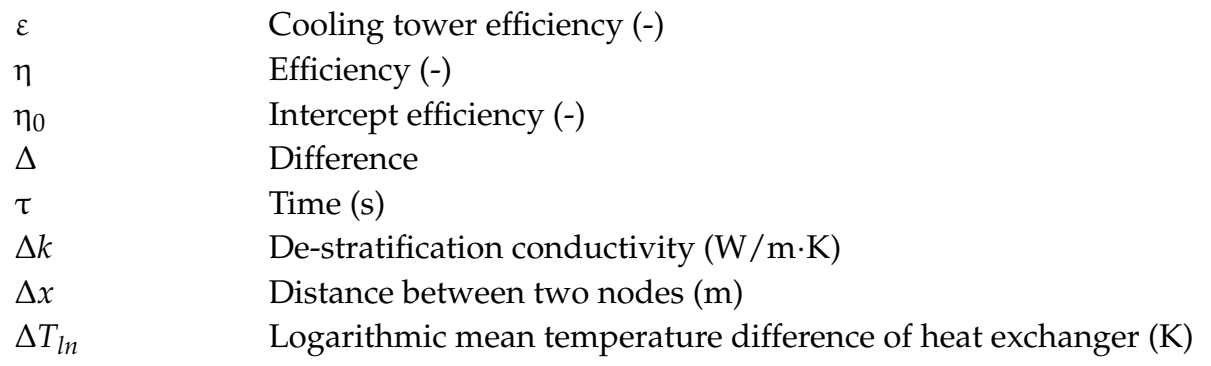




\section{Subscripts}

$\begin{array}{ll}\text { 1in } & \text { Inlet 1 } \\ \text { 1out } & \text { Outlet } 1 \\ \text { 2in } & \text { Inlet } 2 \\ \text { 2out } & \text { Outlet 2 } \\ \text { a } & \text { Air } \\ \text { ava } & \text { Available } \\ \text { c } & \text { Cross-sectional } \\ \text { cell } & \text { Cell } \\ \text { chw } & \text { Chilled water } \\ \text { co } & \text { Cooling } \\ \text { cp } & \text { Cooling operation period } \\ \text { cw } & \text { Cooling water } \\ \text { down } & \text { Down in the tank } \\ \text { el } & \text { Electric } \\ \text { env } & \text { Environment } \\ \text { exp } & \text { Exported } \\ \text { fuel } & \text { Related to fuel } \\ \text { hx } & \text { Heat exchanger } \\ \text { hp } & \text { Heating operation period } \\ i & \text { Generic node } \\ \text { in } & \text { Inlet } \\ \text { loss } & \text { Losses } \\ \text { p } & \text { Primary } \\ \text { ren } & \text { Satisfied by renewable source } \\ \text { req } & \text { Required } \\ \text { s } & \text { Surface } \\ \text { sat } & \text { Saturated condition } \\ \text { sc } & \text { Self-consumed } \\ \text { sol } & \text { Solar } \\ \text { tank } & \text { Storage tank } \\ \text { th } & \text { Thermal } \\ \text { tilt } & \text { On tilted surface } \\ \text { tot } & \text { Total } \\ \text { up } & \text { Up in the } \\ & \end{array}$

\section{Superscripts and Acronyms}

$\begin{array}{ll}\text { AH } & \text { Auxiliary Heater } \\ \text { AHP } & \text { Absorption Heat Pump } \\ \text { AUX } & \text { Auxiliaries } \\ \text { CST } & \text { Cold water Storage Tank } \\ \text { CT } & \text { Cooling Tower } \\ \text { DC } & \text { Dry Cooler } \\ \text { EU } & \text { European Union } \\ \text { GHG } & \text { Greenhouse Gas } \\ \text { GRID } & \text { Grid } \\ \text { HST } & \text { Hot water Storage Tank } \\ \text { HVAC } & \text { Heating Ventilation and Air Conditioning } \\ \text { P1 } & \text { Solar loop pump } \\ \text { P2 } & \text { Fan coil pump } \\ \text { micro-CHP } & \text { Micro Combined Heating and Power } \\ \text { SC } & \text { Solar Collector } \\ \text { SHC } & \text { Solar Heating and Cooling } \\ \text { US } & \text { User }\end{array}$




\section{References}

1. EU Energy in Figures-Statistical Pocketbook 2012. Available online: https://ec.europa.eu/energy/sites/ ener/files/documents/2012_energy_figures.pdf (accessed on 17 February 2016).

2. EU Energy in Figures-Statistical Pocketbook 2014. Available online: http://ec.europa.eu/energy/sites/ ener/files/documents/2014_pocketbook.pdf (accessed on 17 February 2016).

3. Eurostat Statistics Explained. Greenhouse Gas Emissions by Industries and Households. Available online: http:/ / ec.europa.eu/eurostat/statistics-explained/index.php/Greenhouse_gas_emissions_by_ industries_and_households (accessed: 18 February 2016).

4. Sustainable Building and Climate Initiative-United Nations Environment Programme. Buildings and Climate Change: Summary for Decision-Makers. 2009. Available online: http://www.unep.org/sbci/pdfs/SBCIBCCSummary.pdf (accessed on 17 February 2016).

5. International Energy Agency. Technology Roadmap: Solar Heating and Cooling. Available online: https://www.iea.org/publications/freepublications/publication/Solar_Heating_Cooling_Roadmap_ 2012_WEB.pdf (accessed on 22 February 2016).

6. Eurostat Statistics Explained. Electricity Production, Consumption and Market Overview. Available online: http:/ /ec.europa.eu/eurostat/statistics-explained/index.php/Electricity_production,_consumption_ and_market_overview\#Electricity_generation (accessed on 22 February 2016).

7. Capellán-Pérez, I.; Mediavilla, M.; de Castro, C.; Carpintero, Ó.; Miguel, L.J. Fossil fuel depletion and socio-economic scenarios: An integrated approach. Energy 2014, 77, 641-666. [CrossRef]

8. Ghafoor, A.; Munir, A. Worldwide overview of solar thermal cooling technologies. Renew. Sustain. Energy Rev. 2015, 43, 763-774. [CrossRef]

9. International Energy Agency Solar Heating \& Cooling Programme. Available online: http://www.iea-shc. org/ (accessed on 23 February 2016).

10. Shirazi, A.; Taylor, R.A.; White, S.D.; Morrison, G.L. Transient simulation and parametric study of solarassisted heating and cooling absorption systems: An energetic, economic and environmental (3E) assessment. Renew. Energy 2016, 86, 955-971. [CrossRef]

11. TRNSYS 17, Transient System Simulation Tool; Solar Energy Laboratory, University of Wisconsin-Madison: Madison, WI, USA, 2010.

12. Calise, F. High temperature solar heating and cooling systems for different Mediterranean climates: Dynamic simulation and economic assessment. Appl. Therm. Energy 2012, 32, 108-124. [CrossRef]

13. Baniyouners, A.M.; Rasul, M.G.; Khan, M.M.K. Assessment of solar assisted air conditioning in Central Qeensland's subtropical climate, Australia. Renew. Energy 2013, 50, 334-341. [CrossRef]

14. Zhai, X.; Li, Y.; Cheng, X.; Wang, R. Experimental investigation on a solar-powered absorption radiant cooling system. Energy Procedia 2015, 70, 552-559. [CrossRef]

15. Drosou, V.; Kosmopoulos, P.; Papadopoulos, A. Solar cooling system using concentrating collectors for office buildings: A case study for Greece. Renew. Energy 2016, 97, 697-708. [CrossRef]

16. Mohan, G.; Uday Kumar, N.T.; Pokhrel, M.K.; Martin, A. Experimental investigation of a novel solar thermal polygeneration plant in United Arab Emirates. Renew. Energy 2016, 91, 361-373. [CrossRef]

17. Suárez, I.; Prieto, M.; Fernández, F.J. Analysis of potential energy, economic and environmental savings in residential buildings: Solar collectors combined with microturbines. Appl. Energy 2013, 104, 128-136. [CrossRef]

18. Kegel, M.; Tamasauskas, J.; Sunye, R. Solar trigeneration system in Canadian climate multi-unit residential building. Energy Procedia 2014, 48, 876-887. [CrossRef]

19. Ribberink, H.; Lombardi, K.; Yang, L.; Entchev, E. Investigation of a hybrid renewable-microgeneration energy system for power and thermal generation with reduced emissions. J. Power Energy 2012, 227, 62-72. [CrossRef]

20. Muye, J.; Ayou, D.S.; Saravanan, R.; Coronas, A. Performance study of a solar absorption power-cooling system. Appl. Therm. Eng. 2016, 97, 59-67. [CrossRef]

21. Decreto del Presidente della Repubblica n. 59/2009 (Decree of President of Italian Republic No. 59/2009). Available online: http://efficienzaenergetica.acs.enea.it/doc/dpr_59-09.pdf (accessed on 26 April 2016). (In Italian) 
22. Heating Systems in Buildings_-Method for Calculation of the Design Heat Load, EN 12831; European Standard; European Committee for Standardization (CEN): Brussels, Belgium, 2003.

23. Monitoring electricity consumption in the tertiary sector (EL-TERTIARY). Available online: https://ec. europa.eu/energy/intelligent/projects/en/projects/el-tertiary (accessed on 7 March 2016).

24. Caputo, P.; Costa, G.; Canotto, V.; Pistocchini, L.; Roscetti, A. Comportamento della piattaforma in relazione al corretto abbinamento tra curve di domanda e sistemi di generazione e controllo (Behaviour of the Platform in Relation to Proper Combination of Demand Curves and Generation and Control Systems). Available online: http://www.enea.it/it/Ricerca_sviluppo/documenti/ricerca-di-sistemaelettrico/efficienza-energetica-servizi/rds-55.pdf (accessed on 22 April 2016). (In Italian)

25. Impianti aeraulici a fini di benessere-Generalità, classificazione e requisiti- Regole per la richiesta d'offerta, l'offerta, l'ordine ela fornitura (Air conditioning systems for thermal comfort in buildings-General classification and requirements-Offer, order and supply specifications), UNI 10339; Italian Standard: Rome, Italy, 1995. (In Italian)

26. Angrisani, G.; Roselli, C.; Sasso, M.; Tariello, F. Dynamic performance assessment of a micro-trigeneration system with a desiccant-based air handling unit in Southern Italy climatic conditions. Energy Convers. Manag. 2014, 80, 188-201. [CrossRef]

27. Catalogo-Listino n. 03/2016 (Catalog-Price list n. 3/2016). Available online: http:/ /www.thermital.it/files / 7062-0216_catalogolistinoth-fo_03_2016_r0_low1.pdf (accessed on 28 August 2016). (In Italian)

28. WFC-SC Chiller. Available online: http://www.maya-airconditioning.com/english/modules/prodacqua/ pdf/WFC-SC5_Specifications_eng.pdf (accessed on 28 August 2016).

29. TRANSYS v17.0, Thermal Energy System Specialists Components Library v. 17.01; Thermal Energy System Specialists: Madison, WI, USA, 2004.

30. Duffie, J.A.; Beckmann, W.A. Solar Engineering of Thermal Processes, 3rd ed.; Wiley: New York, NY, USA, 2006; pp. 290-312.

31. Arndt, U.; Beausoleil-Morrison, I.; Davis, M.; D’haeseleer, W.; Dorer, V.; Entchev, E.; Ferguson, A.; Gusdorf, J.; Kelly, N.; Manning, M.; et al. Experimental Investigation of Residential Cogeneration Devices and Calibration of Annex 42 Models; Annex 42 of the International Energy Agency Energy Conservation in Buildings and Community Systems Programme: Ottawa, ON, Canada, 2007.

32. Dachs/Dachs SE \& Dachs SE Condensing with MSR2: Instructions for Installation, Assembly, Commissioning, and Operation of the Dachs. Available online: http:/ /www.senertec.co.uk/downloads/ Dachs_with_MSR2_Installation_Guide.pdf (accessed on 27 April 2016).

33. Angrisani, G.; Canelli, M.; Roselli, C.; Sasso, M. Calibration and validation of a thermal energy storage model: Influence on simulation results. Appl. Therm. Eng. 2014, 67, 190-200. [CrossRef]

34. Bollitori, Termoaccumulatori, Montaliquidi, Sistemi Idronici: Catalogo 2015-2016. Available online: http://www.cordivari.it/media/userfiles/files/CAT_BOLLITORI_ITALIA_ERP_2015_NO_PREZZI_R_ 12-2015.pdf (accessed on 6 April 2016). (In Italian)

35. American Society of Heating. 2008 Ashrae Handbook: HVAC Systems and Equipment; Refrigerating and Air-Conditioning Engineers: Atlanta, GA, USA, 2008.

36. Simpson, W.M.; Sherwood, T.K. Performance of small mechanical draft cooling tower. Refrig. Eng. 1946, 52, 525-543. [CrossRef]

37. Henning, H.M.; DöllSolar, J. Solar systems for heating and cooling of buildings. Energy Proced. 2012, 30, 633-653. [CrossRef]

(C) 2016 by the authors; licensee MDPI, Basel, Switzerland. This article is an open access article distributed under the terms and conditions of the Creative Commons Attribution (CC-BY) license (http://creativecommons.org/licenses/by/4.0/). 